\title{
Media concentration of ownership and its effects on editorial page vigor of West Virginia daily newspapers
}

\author{
Rita F. Counts Colistra \\ West Virginia University
}

Follow this and additional works at: https://researchrepository.wvu.edu/etd

\section{Recommended Citation}

Counts Colistra, Rita F., "Media concentration of ownership and its effects on editorial page vigor of West Virginia daily newspapers" (2004). Graduate Theses, Dissertations, and Problem Reports. 1421. https://researchrepository.wvu.edu/etd/1421

This Thesis is protected by copyright and/or related rights. It has been brought to you by the The Research Repository @ WVU with permission from the rights-holder(s). You are free to use this Thesis in any way that is permitted by the copyright and related rights legislation that applies to your use. For other uses you must obtain permission from the rights-holder(s) directly, unless additional rights are indicated by a Creative Commons license in the record and/ or on the work itself. This Thesis has been accepted for inclusion in WVU Graduate Theses, Dissertations, and Problem Reports collection by an authorized administrator of The Research Repository @ WVU. For more information, please contact researchrepository@mail.wvu.edu. 


\title{
Media Concentration of Ownership and its Effects on Editorial Page Vigor of West Virginia Daily Newspapers
}

\author{
Rita F. Counts Colistra
}

Thesis submitted to the Perley Isaac Reed School of Journalism at West Virginia University in partial fulfillment of the requirements for the degree of

Master of Science in Journalism

Terry Wimmer, Ph.D., Chair Ivan Pinnell, Ph.D. George Esper, Ph.D. Carol Zwickel, Ph.D.

Department of Journalism

Morgantown, W.Va. 2004

KEYWORDS: concentration of ownership, editorial vigor, newspaper ownership, West Virginia newspapers

Copyright 2004 Rita F. Counts Colistra 


\section{ABSTRACT \\ Media Concentration of Ownership and its Effects on Editorial Page Vigor of West Virginia Daily Newspapers}

\section{Rita F. Counts Colistra}

This study examines the effects of media concentration of ownership on editorial page vigor of West Virginia daily newspapers that changed from independent to nonindependent ownership from 1965 to present. A content analysis over two-time periods, a one-week constructed sample while under independent ownership and a one-week constructed sample after the newspaper changed to non-independent ownership, suggests that overall editorial page vigor does not change. However, data concerning editorial geographic focus and number of letters to the editor suggest an increase in vigor after moving to non-independent ownership. That is, the newspapers published more locally focused editorials and more letters to the editor while under non-independent ownership rather than while under independent ownership as predicted in the hypotheses. This is the first known study to include columns, as well as editorials and letters to the editor, in an editorial page vigor analysis. An expanded study to include newspapers in similar regions and a larger constructed week sample is suggested. An examination of editorial cartoons, in addition to editorials, columns and letters to the editor, is also suggested for future editorial page vigor research. 


\section{DEDICATION}

This research is dedicated to my brilliant and supportive husband, Kevin, and my faithful four-legged companion Coreopsis Moonbeam. 


\section{ACKNOWLEDGMENTS}

Thanks to Dr. Terry Wimmer for opening my eyes to the wonderful world of media research and for the confidence and encouragement to further my education; Dr. Ivan Pinnell for the many years of encouragement and support; Dr. George Esper for the countless life and classroom lessons and confidence; Dr. Ralph Hanson for the SPSS and statistical assistance; Cathy Miller in Charleston for all of the valuable information on West Virginia newspapers; Eddie Barrett for his keen memory of so many West Virginia newspaper facts; and last but not least, my wonderful husband and proud family-I would not be here without your support. 


\section{TABLE OF CONTENTS}

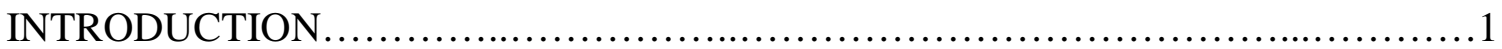

RESEARCH QUESTION......................................................

LITERATURE REVIEW .....................................................4

Theoretical Framework.................................................................................4

Joint Operating Agreement and the Newspaper Preservation Act......................9

Newspaper Ownership Situations and their Effects...............................14

Financial Issues and Profit Maximization...............................14

Homogenization of Content........................................17

Content Quality.................................................19

Editorial Content and Vigor........................................21

What Makes a Good Editorial Page?....................................................23

A Closer Look at Editorial Page Vigor................................26

HYPOTHESES .............................................................29

METHODS.................................................................. 30

A Note on Editorials and Columns............................................38

RESULTS...............................................................42

A Look at the Individual Newspapers.......................................47

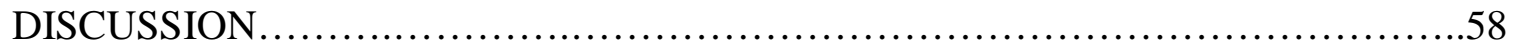

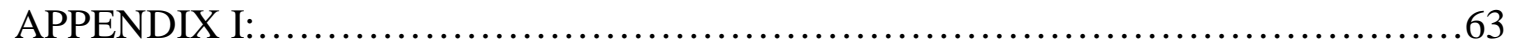

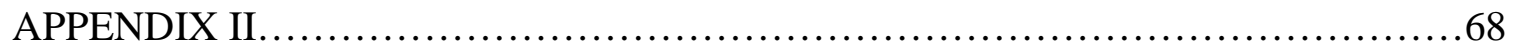

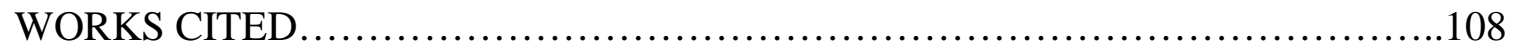




\section{LIST OF TABLES}

Chart 1: Sampling Time Period...............................................33

Table 1: Percentages of Editorial Authorship by Ownership..........................42

Table 2: Percentages of Column Authorship by Ownership.........................43

Table 3: Percentages of Editorial Critical Evaluation by Ownership....................44

Table 4: Percentages of Column Critical Evaluation by Ownership.....................44

Table 5: Percentages of Editorial Focus by Ownership............................45

Table 6: Percentages of Column Focus by Ownership............................46

Table 7: Percentages of Letter Critical Evaluation by Ownership....................47

Table 8: Beckley Post Herald Summary Values..................................47

Table 9: Bluefield Daily Telegraph Summary Values.............................48

Table 10: Percentages of Editorial Focus by Ownership

(Bluefield Daily Telegraph)........................................49

Table 11: Charleston Daily Mail Summary Values................................50

Table 12: Percentages of Editorial Focus by Ownership (Charleston Daily Mail).......51

Table 13: Huntington Herald-Dispatch Summary Values...........................52

Table 14: Percentages of Editorial Focus by Ownership

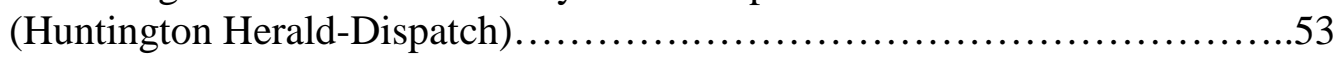

Table 15: (Keyser) Mineral Daily News-Tribune Summary Values....................53

Table 16: Logan Banner Summary Values......................................54

Table 17: Percentages of Editorial Authorship by Ownership (Logan Banner)...........55

Table 18: Raleigh Register Summary Values....................................56 


\section{CHAPTER ONE}

\section{INTRODUCTION}

Media concentration of ownership and its effects on journalistic quality have been highly debated issues ever since chain newspapers began to flourish in the United States. Since chain ownership of newspapers began in the 1800s many people, communications scholars and journalists alike, have contemplated its effects on the media industry. In his early study of the growth of U.S. newspaper chains, Weinfeld found that the first significant growth of chain newspapers, in numbers and circulation, was in the four years following World War I. ${ }^{1}$ By 1923, newspaper chains had already established themselves throughout America with thirty- four different chains. ${ }^{2}$ This rapid growth of chain newspapers continued to spread. In fact, total circulation of chain newspapers had increased by almost $76 \%$ by 1930 , while non-chain owned circulation saw a markedly smaller rise of only $3.4 \%{ }^{3}$ Circulation in the chain newspapers was not the only thing on the rise. After the rough Depression years on both chain and non-chain newspapers, the number of newspaper chains increased rapidly to sixty-three in 1935; non-chains, however, declined. ${ }^{4}$

Busterna continued the study of trends in newspaper ownership in his updated 1986 research. ${ }^{5}$ He found that $68 \%$ of all daily newspapers were independently owned in

\footnotetext{
${ }^{1}$ William Weinfeld, "The Growth of Daily Newspaper Chains in the United States: 1923, 19261935,” Journalism Quarterly 13, no. 4 (1936): 362.

${ }^{2}$ Ibid.

${ }^{3}$ Ibid., 365.

${ }^{4}$ Ibid., 369.

${ }^{5}$ John C. Busterna, “Trends in Daily Newspaper Ownership,” Journalism Quarterly 65 (winter 1988): 831-38.
} 
1960, but by 1986 that number had decreased to only 30\%. ${ }^{6}$ Additionally, Busterna suggested that this increase of chain ownership and chain size resulted in a further decline in the competition of daily newspapers and an increase in absentee ownership. ${ }^{7}$

The question now is how does this change of ownership affect the product the reader receives? More importantly does this trend of ownership change affect the editorial page, which is considered the voice of any newspaper? Has the editorial page become more or less vigorous as a result?

The importance of the editorial page is obvious. As the late reporter and columnist Raymond Clapper put it:

Discussion is the breath of a democracy's life. The constant challenge of one opinion against another is essential. Without it democracy becomes a fragile hothouse growth liable to snap under the first gust of opposition wind. The editorial page is — or should be-America's town hall. The type of debate and the type of newspaper writing that must make a thing either black or white, that must distort it out of all proportion, that take a set of facts or circumstances and are impelled to throw in a dash of sensational overstatement, are an imposition on the public... It is just as inexcusable for a man to throw a verbal stink bomb into a crowd as it would be to sabotage machinery in a defense plant. There is sabotage to public opinion just as there is sabotage to machinery. ${ }^{8}$

With Clapper's statement in mind, the author hopes to provide better insight in understanding the effects of media concentration of ownership on news product, namely editorial page vigor, in an extensive literature assessment. Areas such as financial goals and profits, standardization of content, content quality, and, most importantly, editorial

${ }^{6}$ Ibid., 835.

${ }^{7}$ Ibid., 838.

${ }^{8}$ Raymond Clapper, Watching the World, with an introduction by Ernie Pyle, ed. Olive Ewing Clapper (New York: Whittlesey House, 1944), 35-36. 
quality and aggressiveness will be examined in an attempt to illuminate possible advantages and disadvantages associated with different ownership situations.

Additionally, federal policies and regulations aimed at preserving newspapers and offering options for financial relief will be discussed.

\section{RESEARCH QUESTION}

Does media concentration of ownership have a positive, a negative, or no impact on the product the media audience receives? 


\section{CHAPTER TWO}

\section{LITERATURE REVIEW}

This review of literature seeks to answer the aforementioned research question while examining and interpreting differences in research styles, which often lead to contrasting findings. The author will provide the theoretical framework behind the premise of media concentration of ownership’s effects on news and editorial page decisions. Additionally, the author will review federal acts and agreements put in place to aid troubled newspapers while preserving editorial individuality. Moreover, this review will examine the different areas mentioned earlier believed to be affected by media concentration of ownership.

\section{Theoretical Framework}

As most newspaper ownership situations are unique, so are the practices in which their owners or managers control them. Since its inception to the field of mass communication, gatekeeping research has offered people a better understanding in the way the media function. Not only can editors and reporters act as keeper of the gate, but now with various ownership situations, stockholders and chain owners may also serve as gatekeepers. However, as one study points out, these gatekeeping practices are not always obvious and are sometimes a result of "subtle” pressures felt by editors by their chain owners. ${ }^{9}$

Gatekeeping theory has been around for more than half a century and is one of the

\footnotetext{
${ }^{9}$ Theodore L. Glasser, David S. Allen, and S. Elizabeth Blanks, "The Influence of Chain Ownership On News Play: A Case Study,” Journalism Quarterly 66 (autumn 1989): 613.
} 
most researched fields of communications. German psychologist and expatriate Kurt Lewin first coined the term during his research on social change in times of food shortages following World War II. ${ }^{10}$ Lewin found that food passes through gates using different channels with gatekeepers selecting or rejecting the items that are then delivered to a family’s table. ${ }^{11}$ Although the theory has a psychological background, Lewin implied that this theory of gates and channels could be applied to items of news traveling through different forms of communication paths. ${ }^{12}$

Communications scholar David Manning White was the first to apply Lewin’s theory to media and communications. ${ }^{13}$ His case study focused on one Midwestern newspaper wire editor's story selection process and the forces that affected decisionmaking. ${ }^{14}$ He found that the editor applied both 'individual' and 'organizational' routines that affected which stories would be selected or rejected. ${ }^{15}$ These routine concepts were not named as such until much later. ${ }^{16}$ While his study was limited because it only focused

\footnotetext{
${ }^{10}$ Kurt Lewin, "Frontiers in Group Dynamics: Concept, Method and Reality in Science; Social Equilibria and Social Change,” Human Relations 1 (June 1947): 5-40; Kurt Lewin, "Frontiers in Group Dynamics: Channels of Group Life; Social Planning and Action Research,” Human Relations 1 (November 1947): 143-53.

${ }^{11}$ Kurt Lewin, Field Theory in Social Science: Selected Theoretical Papers, ed. Dorwin Cartwright, (NY: Harper \& Brothers, 1951), 176.

12 Ibid., 187.

${ }^{13}$ David Manning White, “The 'Gate Keeper': A Case Study in the Selection of News,” Journalism Quarterly 27 (fall 1950): 383-90.

${ }^{14}$ Ibid.

${ }^{15}$ Ibid., 386-87.

${ }^{16}$ Pamela J. Shoemaker and Stephen D. Reese, Mediating the Message: Theories of Influences on Mass Media Content, (NY: Longman, 1996), 106.
} 
on one editor's rejection of news items, it spurred a great deal of interest in the theory and began a long line of research that continues to be investigated today.

When discussing gatekeeping, it is essential to note its connection with at least one other study of communications: agenda-setting. The reason is that gatekeepers control the flow of news information through the different mediums and, therefore, set the agenda for the types of news that is printed or aired. McCombs and Shaw's agendasetting research on the 1968 presidential election focused on what voters perceived as key issues versus the issues presented by the media. ${ }^{17}$ They compared the data and found a surprisingly high relationship. ${ }^{18}$ This relationship supports Cohen’s claim that the press "may not be successful much of the time in telling people what to think, but it is stunningly successful in telling its readers what to think about." ${ }^{\text {"19 }}$ McCombs and Shaw's research, therefore, emphasized agenda-setting as a form of gatekeeping in the news. This theory is helpful in understanding media concentration of ownership situations because owners of these different types of newspapers have various agendas they want their medium to portray. Sometimes the mere perception of an agenda influences the gatekeeper's choice in the editorial chain.

Shoemaker and Reese developed a hierarchical model that applies both to modern studies and earlier gatekeeping research. The model proposes that several levels affect

\footnotetext{
${ }^{17}$ Maxwell E. McCombs and Donald L. Shaw, “The Agenda-Setting Function of Mass Media,” Public Opinion Quarterly 36 (1972): 176-87.

${ }^{18}$ Ibid., 182-87.

${ }^{19}$ Bernard Cohen, The Press and Foreign Policy, (Princeton: Princeton University Press, 1963): 120, quoted in McCombs and Shaw, “The Agenda-Setting Function of the Mass Media,” 177.
} 
the gatekeeping process and include: individual, media routine, organizational, extramedia, and ideological. ${ }^{20}$

The individual level involves personal preferences by the reporter, editor, or director. However, different mediums follow different gatekeeping practices. Abbott and Brassfield's study showed that newspapers have several gatekeepers, whereas the initial television gatekeeper tends to make the final decision. ${ }^{21}$ Other gatekeeping studies have found that the decision-making process in television news is based on a group rather than on an individual level. ${ }^{22}$ One Berkowitz study implied that even though television news decisions are made in groups, they are not necessarily balanced groups; the group’s opinion is often swayed by the person in charge. ${ }^{23}$

Studies on media routine levels in gatekeeping involve factors such as newsworthiness and timeliness. ${ }^{24}$ Shoemaker, Eichholz, Kim, and Wrigley found that routines of the media have more control over news content than individual forces. ${ }^{25}$

Organizational routines including available resources, editorial demands, time, and restraints focus on technical levels of gatekeeping. Bantz, McCorkle, and Baade’s

${ }^{20}$ Shoemaker and Reese, Mediating the Message, 106.

${ }^{21}$ Eric A. Abbott and Lynn T. Brassfield, “Comparing Decisions on Releases by TV and Newspaper Gatekeepers,” Journalism Quarterly 66 (winter 1989): 855.

22 Dan Berkowitz, “Refining the Gatekeeping Metaphor for Local Television News,” Journal of Broadcasting \& Electronic Media 34, no. 1 (1990): 55-69; Edward Jay Epstein, News from Nowhere: Television and the News, Vintage Books ed. (NY: Random House, 1974).

${ }^{23}$ Berkowitz, “Refining the Gatekeeping Metaphor for Local Television News,” 69.

${ }^{24}$ Pamela J. Shoemaker et al., “Individual and Routine Forces in Gatekeeping,” Journalism \& Mass Communication Quarterly 78 (summer 2001): 233-242; Gaye Tuchman, Making News: A Study in the Construction of Reality, (NY: Free Press, 1978).

${ }^{25}$ Shoemaker et al., “Individual and Routine Forces in Gatekeeping,” 240. 
study went so far as to compare these routines to a factory. ${ }^{26}$ However, they noted that although news work is accomplished through steps producing uniform product within a given timeframe, it is clearly not an assembly line. ${ }^{27}$

Extra-media levels of gatekeeping refer to sources, advertisers, government, and interest groups among others. Some studies have relied on this level of analysis for research in attempting to get to the first step of the gatekeeping process. ${ }^{28}$ Berkowitz pointed out that in the agenda-building process, the relationship between journalists and news sources should be examined in addition to the newsgathering process. ${ }^{29}$ This relationship should be studied to ensure that the journalist and the news source are not simply affiliated to build one another's agenda. That is, in exchange for the source providing information, the journalist agrees to report on issues the source deems important. To put it in the words of a cliché, the examination is to ensure that a "you scratch my back and I'll scratch yours” association is not in place.

Ideological levels of gatekeeping include local and national values in addition to cultural influences. ${ }^{30}$ Soloski's research found that these factors were included in editor decisions to omit potentially offensive material. ${ }^{31}$ However, the journalists in the study believed it did not affect the ability to inform their readers. ${ }^{32}$

\footnotetext{
${ }^{26}$ Charles R. Bantz, Suzanne McCorkle, and Roberta C. Baade, “The News Factory,” Communication Research 7 (January 1980): 45-68.

${ }^{27}$ Ibid., 64.

${ }^{28}$ Dan Berkowitz, "Television News Sources and News Channels: A Study in Agenda-Building," Journalism Quarterly 64 (autumn 1987): 508-513; Judy VanSlyke Turk, “Information Subsidies and Influence,” Public Relations Review 11, no. 3 (1985): 10-25.

${ }^{29}$ Berkowitz, “Television News Sources and News Channels,” 513.

${ }^{30}$ Denis McQuail, Mass Communication Theory, Third ed., (London: Sage, 1994): 213.
} 
Gatekeeping research proves to be helpful in the issue of media concentration.

Shoemaker and Reese's hierarchical model of the different levels of gatekeeping routines help explain some of the practices used by newspapers under different ownership situations.

\section{Joint Operating Agreement and the Newspaper Preservation Act}

In 1970, the Newspaper Preservation Act (NPA) was enacted by the Congress.

Formerly known as the Failing Newspaper Act in 1967, the NPA was an attempt to save failing newspapers that were having a difficult time competing in a two newspaper market. ${ }^{33}$ As stated in declaration of NPA in Section 2, the policy was "in the public interest of maintaining the historic independence” of U.S. newspapers and the policy permitted joint operating agreements (JOAs) to alleviate “economic distress.”34

Under the NPA, a JOA is defined as:

any contract, agreement, joint venture (whether or not incorporated), or other arrangement entered into by two or more newspaper owners for the publication of two or more newspaper publications, pursuant to which joint or common production facilities are established or operated and joint or unified action is taken or agreed to be taken with respect to any one or more of the following: printing, time, method, and field of application; allocation of production facilities; distribution; advertising solicitation; circulation solicitation; business department; establishment of advertising rates; establishment of circulation rates and revenue distribution:

\footnotetext{
${ }^{31}$ John Soloski, "News reporting and professionalism: Some constraints on the reporting of the news,” Media, Culture, and Society 11 (April 1989): 224-25.

${ }^{32}$ Ibid., 225.

33 John C. Busterna and Robert G. Picard, Joint Operating Agreements: The Newspaper Preservation Act and its Application, (Norwood, NJ: Ablex Publishing Corporation, 1993): 37, ix.

${ }^{34}$ Congress, Senate, Newspaper Preservation Act of $1970,91^{\text {st }}$ Cong., $2^{\text {nd }}$ sess., S.R., 1520 Congressional Record, 116, no. 2, daily ed. (30 January 1970): 2018. The terms Joint Operating Agreement, Joint Operating Arrangement, and Joint Ownership Agreement apply to JOA. The term JOA is referred to those agreements enacted under the NPA of 1970.
} 
Provided, that there is no merger, combination, or amalgamation of editorial or reportorial staffs, and that editorial policies be independently determined. ${ }^{35}$

That is, in communities that could no longer support two competitive newspapers, the newspapers were permitted to share the same operational costs such as printing facilities and advertising and business departments as long as they maintained separate editorial and news operations. Maintaining these separate departments was to ensure that the public had a diverse editorial voice.

In order to be given a JOA, the NPA stated that written consent had to be granted by the Attorney General. ${ }^{36}$ A JOA was permitted only if the Attorney General determined that not more than one of the newspapers was failing. ${ }^{37}$ According to the NPA, a "failing newspaper” is a publication that is in danger of failure or appears to turn into or remain a financial failure. ${ }^{38}$

The first identified joint operation among competing newspapers was in 1933 between the Albuquerque Journal and The Albuquerque Tribune in New Mexico, almost 40 years before the NPA created the term. ${ }^{39}$ Both newspapers at the time had faced decreased revenues over a two-year period. Scripps-Howard, the oldest identifiable

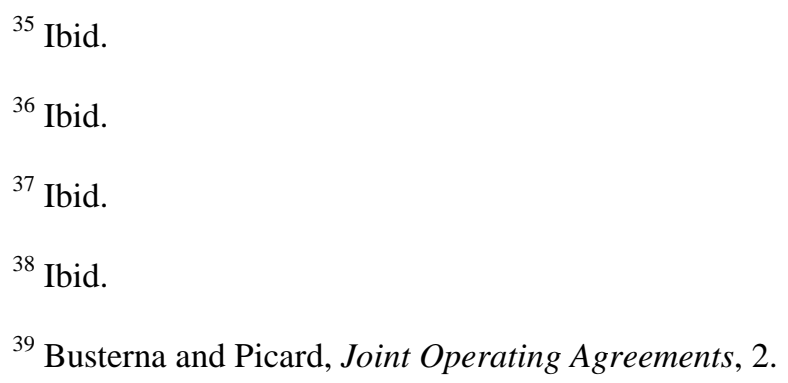


newspaper chain, ${ }^{40}$ merged the two facilities and formed the Albuquerque Publishing Company. ${ }^{41}$ The controversial issue of the agreement, however, was the fact that the two newspapers formed a monopoly. ${ }^{42}$ Both newspapers were non-competitive, under the same circulation and advertising rates, and equally divided all profits. ${ }^{43}$ The monopoly issue would arise in federal court more than 30 years later involving two Arizona newspapers.

The Citizen Publishing Case was born in 1965 when the U.S. Justice Department filed an antitrust suit against two Tucson newspapers running under a JOA. ${ }^{44}$ The newspapers, The Arizona Evening Star and The Tucson Daily Citizen, were charged with violating sections of both the Sherman and Clayton acts regarding monopolizing the daily newspaper market and a merger violation. ${ }^{45}$ The main issue was that when joint operations were agreed upon for the two newspapers, the owners put in writing that if one should decide to sell, the other owner would have first right of refusal. ${ }^{46}$ According to Busterna and Picard, the Justice Department probably would not have interfered with the

\footnotetext{
${ }^{40}$ Weinfeld, “Growth of Daily Newspaper Chains,” 380.

${ }^{41}$ www.sfbg.com/News/joa/timeline.html, Accessed on November 7, 2002.

${ }^{42}$ Ibid.

43 Ibid.

${ }^{44}$ Busterna and Picard, Joint Operating Agreements, 29.

45 Ibid. The Sherman Act violation included Section 1, which deals with a contract in restraint of trade, and Section 2, which deals with monopolizing a daily newspaper market. The Clayton Act charge included Section 7, which deals with the direct purchase of one newspaper by the stockholders of another newspaper in the same market, was a merger violation.
}

${ }^{46}$ United States v. Citizen Publishing, 280 F. Supp. 983 (D. Ariz. 1968). 
newspapers had they not attempted to merge into one. ${ }^{47}$ The U.S. District Court found that the operating agreement was a per se antitrust violation because of the price fixing, market control and profit pooling the newspapers practiced. ${ }^{48}$ The Court deemed that the two newspapers eliminate these practices in addition to maintaining separate advertising and circulation operations in order to restore competition. ${ }^{49}$ Citizen Publishing Company appealed to no avail and in 1969, the Supreme Court upheld the decision with a majority decision written by Justice Douglas. ${ }^{50}$

As noted in the NPA, the newspapers under a JOA are to maintain independent editorial and news departments. Preserving the separate editorial opinions is essential in preserving a diverse “marketplace of ideas.”51 However, studies on diversified opinion under different ownership situations have yielded contrasting results.

Ardoin’s comparative analysis of newspapers under joint printing contracts found that the newspapers do not represent independent voices. ${ }^{52}$ That is, joint operating newspapers tend to homogenize their news output and take similar editorial stances. In contrast, Hick's and Featherston's content analysis of uniformity of content in Louisiana

\footnotetext{
${ }^{47}$ Ibid., 30.
}

${ }^{48}$ Busterna and Picard, Joint Operating Agreements, 33; United States v. Citizen Publishing Co., 280 F. Supp. $992-93$ (D. Ariz. 1968).

${ }^{49}$ Ibid.

${ }^{50}$ Citizen Publishing Co. v. United States, 394 U.S. 131 (1969); Busterna and Picard, Joint Operating Agreements, 30.

${ }^{51}$ John Milton, Areopagitica, with a commentary by Sir Richard C. Jebb (Cambridge: Cambridge University Press, 1918; reprint, New York: AMS PRESS, 1971), 58 (page citation is to the reprint edition); Abrams v. United States, 250 U.S. 616, 629, 40 S. Ct. 17,22 (1919).

${ }^{52}$ Birthney Ardoin, “A Comparison of Newspapers Under Joint Printing Contracts,” Journalism Quarterly 50 (summer 1973): 347. 
newspapers under various forms of ownership implicated the contrary. ${ }^{53}$ The study suggested that opinion content was not duplicated in any of the analyzed newspapers, including the pair under JOA in Shreveport. ${ }^{54}$ Even though no editorial uniformity was found, the study did, however, find similarities in general news content throughout all newspapers. $^{55}$

Differences in findings of the two studies are perhaps due to the variations of samples and sample size. The latter study focused only on newspapers in one state under three different ownership circumstances, only one situation of which was operating under JOA. ${ }^{56}$ Yet, Ardoin's earlier study compared newspapers under JOAs throughout the United States. ${ }^{57}$ Moreover, the data were collected during two critical periods in newspaper history: before the Justice Departments antitrust lawsuit against the two Tucson newspapers and after the Court's decision against the agreement. ${ }^{58}$ Hicks and Featherston's research was more focused on content and appearance differences between morning and evening editions of a sample of the state’s newspapers. ${ }^{59}$

In sum, the JOA and NPA were designed to preserve financially troubled newspapers in market by sharing printing and business operating costs while maintaining

\footnotetext{
${ }^{53}$ Ronald G. Hicks and James S. Featherston, “Duplication of Newspaper Content in Contrasting Ownership Situations,” Journalism Quarterly 55 (autumn 1978): 549-53.

${ }^{54}$ Hicks and Featherston, “Content in Contrasting Ownership Situations,” 551.

${ }^{55}$ Ibid., 553.

${ }^{56}$ Ibid., 550.

${ }^{57}$ Ardoin, “Newspapers Under Joint Printing Contracts,” 341.

58 Ibid.

${ }^{59}$ Hicks and Featherston, “Content in Contrasting Ownership Situations,” 549-53.
} 
independent editorial voices. The NPA, however, continues to have opponents and remains a target of criticism. For example, in the 1980s, JOA newspapers were accused of competing unlawfully with non-JOA newspapers by abusing their antitrust exemptions. ${ }^{60}$ Furthermore, in the early nineties, JOA opponents went so far as attempting to have the NPA abolished. ${ }^{61}$ According to one critic, the Newspaper Preservation Act is failing to preserve many troubled newspapers. ${ }^{62}$

\section{Newspaper Ownership Situations and their Effects}

\section{$\underline{\text { Financial Issues and Profit Maximization }}$}

Media and communications scholars have had a field day researching the possible effects of ownership on several newspaper issues. One issue, financial goals, has been a part of numerous studies involving media concentration. ${ }^{63}$ Chain newspapers are characteristically perceived as forcing mainly profit-driven material. At least one study supports the notion that they are only interested in "all the news that makes a profit.”64

\footnotetext{
${ }^{60}$ Busterna and Picard, Joint Operating Agreements, 3.
}

${ }^{61}$ Ibid.

${ }^{62}$ Busterna, “Trends in Daily Newspaper Ownership,” 834.

63 John C. Busterna, "How Managerial Ownership Affects Profit Maximization in Newspaper Firms,” Journalism Quarterly 66 (summer 1989): 302-07, 358; William B. Blankenberg and Gary W. Ozanich, "The Effects of Public Ownership on the Financial Performance of Newspaper Corporations," Journalism Quarterly 70 (spring 1993): 68-75; Stephen Lacy, Mary Alice Shaver, and Charles St. Cyr, "The Effects of Public Ownership and Newspaper Competition on the Financial Performance of Newspaper Corporations: A Replication and Extension," Journalism \& Mass Communication Quarterly 73 (summer 1996): 332-41; Martha N. Matthews, "How Public Ownership Affects Publisher Autonomy,” Journalism \& Mass Communication Quarterly 73 (summer 1996): 342-53; Clarice N. Olien, Phillip J. Tichenor, and George A. Donohue, "Relation Between Corporate Ownership And Editor Attitudes About Business," Journalism Quarterly 65 (summer 1988): 259-66; Gilbert Cranberg, Randall Bezanson, and John Soloski, Taking Stock: Journalism and the Publicly Traded Newspaper Company, (Ames, Iowa: Iowa State University Press, 2001). 259-66.

${ }^{64}$ Olien, Tichenor, and Donohue, “Corporate Ownership and Editor Attitudes About Business,” 
This notion suggests that corporate executives act as a sieve, allowing only profit-driven news items to seep through. That is, they are serving as gatekeepers controlling the flow of information received by the audience with a motive primarily of financial self interest. Non-independent newspapers have often been viewed as placing profits and financial expectations above journalistic quality. ${ }^{65}$ For example, Lacy, Shaver, and St. Cyr conducted a study concerning publicly owned newspaper groups and their effects on financial performance and competition. ${ }^{66}$ Since publicly owned newspapers, as the study points out, have more constituencies than the traditional newspaper, they are more bound to profit concerns. ${ }^{67}$ Instead of just answering to employees, readers, and advertisers, the publicly traded newspapers must answer to stockholders and financial analysts as well. ${ }^{68}$ However, another study found that journalists from both group and individually owned newspapers did not see the newspapers’ profit-seeking goals as negatively affecting coverage or information diversity. ${ }^{69}$ Still, it is important to point out that just because journalists from group and independently owned papers did not differ much on their opinions, a "sizeable minority" of those responding recognized negative effects due to the profit goals. $^{70}$

${ }^{65}$ Lacy, Shaver, and St. Cyr, "Effects of Public Ownership and Competition on Financial Performance,” 332-41; Busterna, “How Managerial Ownership Affects Profit Maximization,” 301-25.

${ }^{66}$ Lacy, Shaver, and St. Cyr, "Effects of Public Ownership and Competition on Financial Performance,” 332-41. See also, Blankenberg and Ozanich, "Effects of Public Ownership on Financial Performance," 68-75.

${ }^{67}$ Lacy, Shaver, and St. Cyr, "Effects of Public Ownership and Competition on Financial Performance,” 339.

${ }^{68}$ Ibid.

69 David C. Coulson, “Impact of Ownership on Newspaper Quality,” Journalism Quarterly 71 (summer 1994): 408.

${ }^{70}$ Ibid. 
Other studies of newspaper profit maximizing goals deal with different authority positions and managerial roles, and show conflicting results. A study on types of managerial ownership and its effects on profit goals found that non-owner newspaper managers placed more emphasis on building profits than owner managers. ${ }^{71}$ This finding contrasts economic theory, which holds that owner managers place higher emphasis on profits, but supports many journalists' contentions. ${ }^{72}$ Additionally, results suggest that local newspaper owners seem to be in business for reasons beyond maximizing profits. ${ }^{73}$

Again, this idea of profit focus by chain newspapers has had different findings. In their 1985 survey of Minnesota editors, Olien, Tichenor, and Donohue found that editors of locally owned, individual newspapers are more concerned with profits than group owned counterparts. ${ }^{74}$ The authors maintain that this concern is most likely because editors at individual papers often have to serve two separate roles of editor and owner. ${ }^{75}$ This contention, then, would seem to contrast the study discussed earlier that suggested non-owner managers placed greater emphasis on profits. ${ }^{76}$ This contradiction can most likely be attributed to different methodologies and sample size. For example, the study concerning managers used a direct survey in order to measure attitudes toward

${ }^{71}$ Busterna, “How Managerial Ownership Affects Profit Maximization,” 307.

${ }^{72}$ Ibid., 306.

${ }^{73}$ Ibid., 307.

${ }^{74}$ Olien, Tichenor, and Donohue, “Corporate Ownership and Editor Attitudes About Business,” 264.

${ }^{75}$ Ibid., 262.

${ }^{76}$ Busterna, “How Managerial Ownership Affects Profit Maximization,” 307. 
maximizing profits and consisted of a small sample size. ${ }^{77}$ The Minnesota study used an interview method of editors analyzing ownership while using a much larger sample size. ${ }^{78}$ A similar study found that publishers [emphasis added] of publicly owned chains placed greater emphasis on profits than privately owned chain publishers. ${ }^{79}$ The study is worth mentioning even though it did not take into account non-chain newspapers because it gives more insight to the practices of publicly owned chains.

\section{$\underline{\text { Homogenization of Content }}$}

One of the most debated claims concerning media ownership concentration is that it causes a homogenization of the news. That is, non-independent newspapers are usually charged with duplicating news content throughout their chain which, in turn, leads to uniformity in both editorial views and spins taken on certain issues. Several studies have taken on the issue of news standardization finding different results.

Hicks and Featherston found no significant opinion or feature content duplication among Louisiana newspapers under different forms of ownership. ${ }^{80}$ Additionally, Wagenberg and Soderland discovered no theme selection or partisanship standardization throughout chain newspapers in the 1972 Canadian Federal election. ${ }^{81}$ Other studies concerning political issues found otherwise. ${ }^{82}$ For example, Akhavan-Majid, Rife, and

${ }^{77}$ Ibid., 304-05. 263.

${ }^{78}$ Olien, Tichenor, and Donohue, “Corporate Ownership and Editor Attitudes About Business,”

${ }^{79}$ Matthews, “How Public Ownership Affects Publisher Autonomy,” 351.

${ }^{80}$ Hicks and Featherston, “Content in Contrasting Ownership Situations,” 551, 553.

${ }^{81}$ Ronald H. Wagenberg and Walter C. Soderlund, "The Influence of Chain-Ownership on Editorial Comment in Canada,” Journalism Quarterly 52 (spring 1975): 98. 
Gopinath examined Gannett versus similar non-Gannett papers in their study of ownership involving national political issues in $1989 .{ }^{83}$ The researchers compared editorial positions taken on three predetermined public issues by 56 Gannett newspapers and 155 other newspapers. ${ }^{84}$ They found that chain ownership causes standardization on policy issues and editorial positions, although the Gannett papers were more likely to take positions. ${ }^{85}$ However, the authors of the study warned that research on a different set of public issues and additional chains need to be explored before their findings can be generalized. ${ }^{86}$ This warning can be attributed to the examination of only one chain and a limited set of issues.

Differences in findings among these studies can be explained through variations including, but not limited to, location, time period, and samples studied. For example, two obvious differences can be noted between the two political issue studies of Wagenberg and Soderlund and Akhavan-Majid, Rife, and Gopinath. First, the studies took place in two different countries. This observation does not serve to discredit the former study because behaviors of chains are most likely going to be comparable within similar parts of the world. Second, the studies took place at two different time periods; the former in the 1970s and the latter in the late 1980s. Another probable cause of the

${ }^{82}$ Roya Akhavan-Majid, Anita Rife, and Sheila Gopinath, "Chain Ownership and Editorial Independence: A Case Study of Gannett Newspapers,” Journalism Quarterly 68 (spring/summer 1991): 59-66; Daniel Wackman, Donald Gillmor, Cecilie Gaziano, and Everette Dennis, "Chain Newspaper Autonomy as Reflected in Presidential Campaign Endorsements,” Journalism Quarterly 52 (autumn 1975): 411-19.

\footnotetext{
${ }^{83}$ Akhavan-Majid, Rife, and Gopinath, “Chain Ownership and Editorial Independence,” 59-66.

84 Ibid, 59.

85 Ibid, 66.

${ }^{86}$ Ibid.
} 
contrasting findings is the distinct sample size differentiation, which seems to be a factor in most conflicting studies.

Another study related to uniformity is Glasser, Allen, and Blanks’ study of chain ownership influence on news play. ${ }^{87}$ They found that Knight-Ridder chain newspapers not only gave more "play” to the Gary Hart story, but more extensive homogeneity in front page "play" than non-affiliated newspapers. 88 "Play" refers to the location and news hole size dedicated to the story. This finding suggests that chain newspapers may exert organizational gatekeeping forces on their member newspapers. That is, organizational routines, according to Shoemaker and Reese's hierarchical model, can nudge other members of the chain to "play up” a story more. ${ }^{89}$ This seems especially evident in the Gary Hart story case because a major Knight-Ridder newspaper broke the story.

\section{Content Quality}

Another highly examined area of research is the effect of ownership on news content quality. One interesting study analyzed the news content of the Louisville Courier-Journal after purchase by Gannett. ${ }^{90}$ In their study, Coulson and Hansen found that when measured against the increased size of the news hole, hard news coverage actually decreased. ${ }^{91}$ According to Coulson and Hansen, hard news coverage offers 607-14.

${ }^{87}$ Glasser, Allen, and Blanks, “The Influence of Chain Ownership On News Play: A Case Study,”

${ }^{88}$ Ibid., 612-13.

${ }^{89}$ Shoemaker and Reese, Mediating the Message,

${ }^{90}$ David C. Coulson and Anne Hansen, "The Louisville Courier-Journal's News Content after Purchase by Gannett,” Journalism \& Mass Communication Quarterly 72 (spring 1995): 205-15. 
readers a better chance to inform themselves on serious topics. ${ }^{92}$ In contrast, Demers’ study tested a theory of corporate newspaper effects, which included product quality. ${ }^{93}$ Demers found that newspapers possessing more corporate characteristics actually place greater [emphasis added] emphasis on product quality. ${ }^{94}$

The contrasting findings of the studies can best be explained by the different sample sizes, time periods of the samples, and methods. The first study focused on just one newspaper during longer time periods while the latter used data from several newspapers during a much shorter time period. For example, Coulson and Hansen conducted a longitudinal study of the Louisville Courier-Journal's content during two periods: two years prior to Gannett's purchase and two years following change of ownership. ${ }^{95}$ Demers, on the other hand, mailed questionnaires and studied editorial and opinion page tear sheets of 223 newspapers over a two-day period. ${ }^{96}$ Although the sample size in Demers’ study was clearly larger, the time period examined was much shorter than the earlier study.

${ }^{91}$ Ibid., 210. According to this study by Coulson and Hansen, news hole refers to non-advertising space excluding the masthead, flag, folios, and standing section heads, but including display and classified content. Hard news coverage refers to event or decision-oriented stories concerning subjects such as government, the economy, or international affairs.

92 Ibid.

93 David Pearce Demers, The Menace of the Corporate Newspaper: Fact or Fiction?, (Ames, Iowa: Ames University Press, 1996): 277-302.

${ }^{94}$ Ibid., 294.

${ }^{95}$ Coulson and Hansen, “Louisville Courier-Journal’s Content,” 207.

${ }^{96}$ Demers, Menace of the Corporate Newspaper, 278. 


\section{$\underline{\text { Editorial Content and Vigor }}$}

One of the most explored avenues of research concerning media concentration of ownership is its effects on editorial content. Studies investigating newspaper ownership's effects on editorial aggressiveness have produced conflicting results. In his study of West Coast newspapers, Thrift found that vigor in the editorials of independently owned dailies declined after being purchased by chains. ${ }^{97}$ Yet, newspapers that remained independent during the same periods increased in vigor. ${ }^{98}$ This finding falls in line with other evidence suggesting that group purchase of newspapers does not necessarily serve as a benefit to readers. ${ }^{99}$ Similarly, in their study of chain editorial autonomy during presidential campaigns, Wackman, Gillmore, Gaziano, and Dennis suggested that chain ownership discouraged editorial independence when endorsing candidates. ${ }^{100}$ This suggestion, then, would translate into a decrease in editorial vigor.

In contrast, Akhavan-Majid and Boudreau's study of the impact of chain ownership on content found that chain ownership may not have a significant effect on editorial role perceptions. ${ }^{101}$ Editorial role perceptions refer to the manner in which newspaper editors identify their editorial mission. ${ }^{102}$ In fact, the study’s findings suggest

${ }^{97}$ Ralph R. Thrift, Jr., "How Chain Ownership Affects Editorial Vigor of Newspapers.”

Journalism Quarterly 54 (summer 1977): 329.

${ }^{98}$ Ibid.

${ }^{99}$ Gerald L. Grotta, “Consolidation of Newspapers: What Happens to the Consumer?,” Jouralism Quarterly 48 (summer 1971): 245-50; Coulson and Hansen, "The Louisville Courier-Journal's Content after Purchase by Gannett," 205-15; Hicks and Featherston, "Content in Contrasting Ownership Situations," 549-53.

${ }^{100}$ Wackman et al., “Chain Autonomy in Presidential Campaign Endorsements,” 420.

${ }^{101}$ Roya Akhavan-Majid and Timothy Boudreau, "Chain Ownership, Organizational Size, and Editorial Role Perceptions,” Journalism \& Mass Communication Quarterly 72 (winter 1995): 871.

102 Ibid., 863. 
that as the size of the chain increases, activist values of the editors increase. ${ }^{103}$ These activist values, in turn, mean a higher level of aggressiveness. Demers' study of the effect of corporate newspaper structure on editorial page vigor found that newspapers showing characteristics of the corporate form produced a higher number and proportion of staff-generated editorials. ${ }^{104}$ Newspapers exhibiting those characteristics also published a greater number and proportion of editorials and letters to the editor that were critical of mainstream groups or values, a trait he applied to editorial page vigor. ${ }^{105}$ However, his study suggested no significant relationship between editorial-page content and chain ownership. ${ }^{106}$

Still, other studies have generated mixed results or few differences at all. For example, Wagenberg and Soderlund found that socio-cultural issues, local interests, and editorial writer preferences were more influential in editorial coverage than type of ownership. ${ }^{107}$ In fact, they found neither consistent patterns uniting the Free Press chain, nor persistent differences between the chain and independent papers. ${ }^{108}$ In another study, Grotta found no significant differences between independent and chain ownership

${ }^{103}$ Ibid., 870.

${ }^{104}$ David Demers, “Corporate Newspaper Structure, Editorial Page Vigor, and Social Change,” Journalism \& Mass Communication Quarterly 73 (winter 1996): 868-9.

${ }^{105}$ Ibid., 870.

${ }^{106}$ Ibid.

${ }^{107}$ Wagenberg and Soderlund, "The Influence of Chain-Ownership on Editorial Comment in Canada," 96.

${ }^{108}$ Ibid, 94. 
situations. ${ }^{109}$ The study examined the effect of newspaper concentration of ownership under varying situations and the potential benefits passed onto consumers.

The contrasting findings can be attributed to a few different factors, namely time period, samples studied, and methods. The most obvious factors are the differences in time periods and methods. For example, examine Thrift's study in comparison to that of Akhavan-Majid and Boudreau's. Thrift studied and coded editorials from two different time periods: 1960 and 1975, while Akhavan-Majid and Boudreau drew a sample of editors from the 1992 Editor and Publisher yearbook. It is important to point out that the earlier study used a method of coding editorials from prior newspapers while the latter relied on questionnaire information obtained from different editors. It is equally important to mention the differentiation of samples studied. Thrift compared editorial content of newspapers which were independently owned in 1960 but were purchased by a chain by 1975. Akhavan-Majid and Boudreau’s study relied on information obtained solely from chain newspapers.

\section{What Makes a Good Editorial Page?}

Before delving into the main premise of the study, editorial page vigor, it is important to ask one question: What makes a good editorial page? Ernest Hynds' studies have helped shed light on the changing roles of editorials and editorial pages. In his 1983 study on the vital roles of opinion pages, a follow-up to his 1975 research, Hynds mailed a four-page questionnaire to $25 \%$ of the nation's daily newspapers. ${ }^{110}$ He found that $97 \%$ of all surveyed editors agreed that the editorial page should provide a forum for the

${ }^{109}$ Grotta, “Consolidation of Newspapers: What Happens to the Consumer?,”250. 
exchange of information and opinion, while $94 \%$ agreed it should give leadership to the community through stands on issues. ${ }^{111}$ In Simurda's 1997 study of opinion pages, Edward C. Jones, managing editor and former editorial editor of The Free Lance-Star in Fredericksburg, Virginia said, “There is a great hunger among people to listen to an informed and reasoned voice to help them sort things out. Taking positions strongly and clearly is what we need to be doing."

In regards to editorials alone, Hynds' found that $84 \%$ of the surveyed editors claimed that the editorials help readers in making judgments, 60\% said they reinforced opinions already held, and 32\% said they caused readers to change their minds on issues. ${ }^{113}$ Editorial experts in Simurda’s study agreed that when an editorial taps an issue that is important to its readers and makes a strong statement, it can still play a big role in shaping public opinion and political decisions. ${ }^{114}$ In Simurda’s research, Michael G. Gartner, editor of The Daily Tribune in Ames, Iowa, and winner of the 1997 Pulitzer Prize for editorial writing simply claimed that you can’t have a good editorial without facts. ${ }^{115}$ According to the study, this leads the editorial writers back to doing more reporting. $^{116}$

110 Ernest Hynds, "Editorials, Opinion Pages Still Have Vital Roles at Most Newspapers,” Journalism Quarterly 61 (autumn 1984): 634-39.

${ }^{111}$ Ibid, 635.

112 Stephen J. Simurda, “Trying to Make Editorials Sing,” Columbia Journalism Review 36 (September/October 1997): 47.

${ }^{113}$ Hynds, “Editorials, Opinion Pages Still Have Vital Roles at Most Newspapers,” 636.

${ }^{114}$ Simurda, “Trying to Make Editorials Sing,” 48.

115 Ibid.

${ }^{116}$ Ibid. 
Almost all newspapers use columns on their editorials pages. ${ }^{117}$ However, the reasoning behind the selection of columns seems to vary. Hynds' studies suggest that political analyses are the most popular and that most newspapers rely on syndicates for their columns. ${ }^{118}$ However, the use of syndicates does not necessarily mean a better editorial page. In Simurda’s more recent study, John Zakarian, editorial page editor of The Hartford Courant, said, “[Syndicated columnists] are just a cheap way to put out an editorial page.”119 To move away from this, some newspapers editors have sought columns from people within their communities. ${ }^{120}$ This trend could suggest that newspaper staffs are looking for stories that are locally focused and, in turn, spark a higher interest in readers. In fact, the editors in Hynds’ studies said they selected columnists for their ability to draw readers, rather than for their philosophies. ${ }^{121}$ Moreover, a mere 6\% of editors in Hynds’ 1992 survey claimed to run columnists with philosophies similar to those of the newspaper, as compared to $13 \%$ of the editors surveyed in $1983 .^{122}$

${ }^{117}$ Hynds, "Editorials, Opinion Pages Still Have Vital Roles at Most Newspapers," 637; Ernest C. Hynds, “Editors at Most U.S. Dailies See Vital Roles for Editorial Page,” Journalism Quarterly 71 (autumn 1994): 577.

${ }^{118}$ Hynds, "Editorials, Opinion Pages Still Have Vital Roles at Most Newspapers,” 637; Hynds, "Editors at Most U.S. Dailies See Vital Roles for Editorial Page,” Journalism Quarterly 71 (autumn 1994): $577-78$.

${ }^{119}$ Simurda, “Trying to Make Editorials Sing,” 49.

${ }^{120}$ Ibid.

${ }^{121}$ Hynds, "Editorials, Opinion Pages Still Have Vital Roles at Most Newspapers,” 637; Hynds, “Editors at Most U.S. Dailies See Vital Roles for Editorial Page,” Journalism Quarterly 71 (autumn 1994): 578.

${ }^{122}$ Ibid. 
Letters to the editor were ranked the best-read item on the editorial page by the editors surveyed in Hynds’ 1983 study. ${ }^{123}$ In fact, in Simurda’s analysis, Ken Neal, editorial page editor of the Tulsa World in Oklahoma said, “I'd like to think readers can't wait to read the editorials, but I know they really read the letters." ${ }^{\text {,124 }}$ And, according to Hynds’ research, newspapers have been publishing more letters to the editor over the years of his studies. In 1975, 95\% of the surveyed editors received at least 100 letters per year, as compared to $98 \%$ in 1983 and 100\% in $1992 .{ }^{125}$ Most editors in the 1992 survey claimed to print the same percentage of letters, which meant more letters than in past years. ${ }^{126}$ Newspapers' staffs, then, have most likely realized that publishing their readers' voices is the best way to lure them to read other editorial page items such as editorials and columns.

\section{A Closer Look at Editorial Page Vigor}

The basis of this research comes from a curiosity spurred after reading Thrift's study on editorial vigor. Thrift coded 24 West Coast dailies' editorials for two different time periods between 1960 and 1975. ${ }^{127}$ The study followed ownership patterns of these newspapers, which changed from independent to chain ownership during the time periods, to track possible changes in editorial vigor. ${ }^{128}$ Rather than defining editorial

\footnotetext{
${ }^{123}$ Hynds, "Editorials, Opinion Pages Still Have Vital Roles at Most Newspapers,” 635.

${ }^{124}$ Simurda, “Trying to Make Editorials Sing,” 52.

${ }^{125}$ Hynds, “Editors at Most U.S. Dailies See Vital Roles for Editorial Page,” 579.

${ }^{126}$ Ibid.

${ }^{127}$ Thrift, “How Chain Ownership Affects Editorial Vigor,” 328.

${ }^{128}$ Ibid.
} 
vigor, Thrift assigned attributes suggested by editorial writers and authors of texts on editorials. ${ }^{129}$ From his initial background research, Thrift decided that in order for an editorial to be considered vigorous it should 1) focus on a local topic, 2) be written in the argumentative form, 3) have a controversial context, and 4) provide mobilizing information. $^{130}$

Thrift's study is limited, however, because it examined editorials alone, which only make up one aspect of the editorial page. The current study tested not only the editorials, but letters to the editor and editorial page columns as well. Additionally, different characteristics were assigned to form a new basis for editorial page vigor, including mainly those from Demers' study. This is the first known study to include columns in examining the vigor of the editorial page.

Columns are important to include in any study of editorial page vigor because the views and information expressed by the columnists have the opportunity to sway opinion and, therefore, have an impact on a community. Tony Marrow, editor of the late New York Newsday, contends in a 2002 article by Brian Toolan that "With so much raw data and information being hurled at citizens from so many different outlets.....there is a case to be made that columnists are more important than ever, bringing insight, perspective and reasoned argument to bear. And when they're at their best, they do it in a framework that...captures the mood, pace and tone of the city they’re based in.”131

\footnotetext{
129 Ibid., 327.

130 Ibid.

131 Brian Toolan, "What Ever Happened to the Local Columnists?,"
} www.asne.org/search/index.cfm, Accessed on 04-22-03: 4-5. 
Letters to the editor is another editorial page item excluded from Thrift's study. This item is clearly one that should not be overlooked because it provides readers the opportunity to have their voices heard. According to MacDougall, it is the best-read feature on the editorial page. ${ }^{132}$ By encouraging readers to express their opinions, newspapers keep in better touch with the public and can measure the effectiveness of its own operation. ${ }^{133}$ Demers included letters in his 1996 research, but chose to omit columns. $^{134}$

For the purposes of this study, editorials and columns were considered vigorous if the content 1) was critical of an issue associated with a mainstream individual or group, 2) was focused on a local issue, and/or 3) was staff-produced. Letters to the editor were considered vigorous if the content was critical of an issue associated with a mainstream individual or group. These characteristics will be discussed more thoroughly in the methods section.

${ }^{132}$ Curtis D. MacDougall, Principles of Editorial Writing, (Dubuque, Iowa: WM. C. Brown Co., 1973): 141.

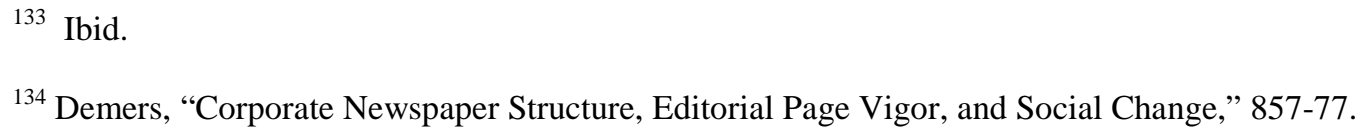




\section{CHAPTER THREE}

\section{HYPOTHESES}

In reviewing the evidence examined in the literature review above, the author hypothesized that before their purchase by a non-independent, independently owned daily newspapers will show more editorial page vigor. That is, prior to change of ownership, the independent dailies will:

H1: publish more staff-produced editorials.

H2: publish more staff-produced columns.

H3: publish more editorials that are critical of mainstream groups.

H4: publish more columns that are critical of mainstream groups.

H5: publish more editorials that are focused on local issues.

H6: publish more columns that are focused on local issues.

H7: publish more letters to the editor.

H8: publish more letters to the editor that are critical of mainstream groups. 


\section{CHAPTER FOUR}

\section{METHODS}

All West Virginia daily newspapers that changed from independent to nonindependent ownership from 1965 to present were included in this study; a total of seven newspapers. West Virginia daily newspapers were chosen because the author sought to determine whether newspapers in a more rural, economically challenged state follow similar trends as those in similar parts of the country.

In order to be included in the study, a newspaper had to 1) publish an opinion/editorial page at least one time per week and 2) be a West Virginia daily newspaper that moved from independent to non-independent ownership from 1965 to present. Only the first change of ownership was considered. For example, suppose that a newspaper was independently owned in 1965, purchased by a chain in 1968 and then purchased by a different chain in 1970 . For the purposes of this study, only the first change of ownership from independent to non-independent was examined, which would be the purchase in 1968.

A daily newspaper is defined as any newspaper that publishes at least five times per week. Those newspapers that collaborated with another for Saturday and/or Sunday issues were also included in the study. Additionally, only newspapers that were in publication at the time of the study were used. However, if a portion of the newspaper was still in existence at the time of analysis, it was considered. For example, the Raleigh Register was no longer a sole publication during the time of research. However, it was included because, after the sample period, it merged with the Beckley Post Herald to 
form the Beckley Register-Herald, which was still in existence at the time of the study. Therefore, a portion of the Raleigh Register was still published during this examination and, hence, qualified for analysis.

Two categories of ownership were addressed in this study: independent and nonindependent. Ownership was determined by consulting the West Virginia Secretary of State's office and website, speaking with individuals from the newspapers, examining the West Virginia Blue Books, and referring to anniversary editions of the newspapers. ${ }^{135}$ An independent newspaper, also known as "individual” or "family-owned," is defined as one under private ownership that is not associated with a private or public chain or group. It is a single newspaper that is owned and managed by the same individual or family. ${ }^{136}$ If an individual or family owns and/or manages more than one newspaper, the publication is not considered independent. The exception in this study is the Raleigh Register. The Hodel family owned both the Beckley Post-Herald and the Raleigh Register, both in the same region. The Hodels sold the two newspapers, which later merged, to Clay Communications. Since the papers were sold together and the Raleigh Register is only in partial existence today as the Beckley Register-Herald, it was considered an independent for the purposes of this study.

A non-independent newspaper is defined as a chain or group newspaper in the same or different cities under the same ownership or control. If an individual or family owns and/or manages more than one newspaper, the publication is considered non-

${ }^{135}$ The West Virginia Blue Books are reference items published each year by the state. The books offer information about the state's government, political subdivisions, county facts and figures, officials, holidays, media entities, etc.

${ }^{136}$ Demers, “Corporate Newspaper Structure, Editorial Page Vigor, and Social Change,” 858. 
independent. For the purposes of this study, as soon as the individual or family purchases a newspaper other than their flagship publication, they change from independent to a nonindependent ownership status. Newspapers that are publicly owned or publicly traded entities are also included as non-independents. ${ }^{137}$

The study also provides an analysis of the individual newspapers. This will provide a better understanding of the effects of chain size or type when examining editorial page vigor as compared to independent newspapers.

As with Thrift's study, the editorial page was coded for two time periods: prior to the purchase by a chain and after purchase by a chain. ${ }^{138}$ Two constructed one-week periods were selected from each newspaper in the study. ${ }^{139}$ The first constructed oneweek sample was derived from a six-month period, which was at least six months but not more than 12 months, prior to the point of sale. The six months immediately prior to the point of sale were not coded since talks of the sale may have already begun and, therefore, possibly affected the editorial page’s content. A six-month leeway period from the point of sale was then allowed for the "settling in" of new ownership. The second constructed one-week sample was derived from the six month period, which was at least six months but not more than 12 months, after the after the point of sale. A visual explanation of the leeway and sample periods is shown in Chart 1.

137 According to Matthews, a publicly owned or traded newspaper shares characteristics of a chain, except that shares of the newspapers' stock are issued and traded on stock exchanges.

138 Thrift, “How Chain Ownership Affects Editorial Vigor,” 328.

139 Each day was pulled at random from a six-month period, at least six months but not more than 12 months, prior to the ownership change until two one-week periods were obtained for each newspaper. That is, all Mondays in a given newspaper's six-month time period were placed in a hat and one Monday was drawn (the remaining days of the week followed suit until a constructed one-week period was drawn). The same method was used for the constructed one-week period after the change in ownership. 


\section{CHART 1. Sampling Time Period}

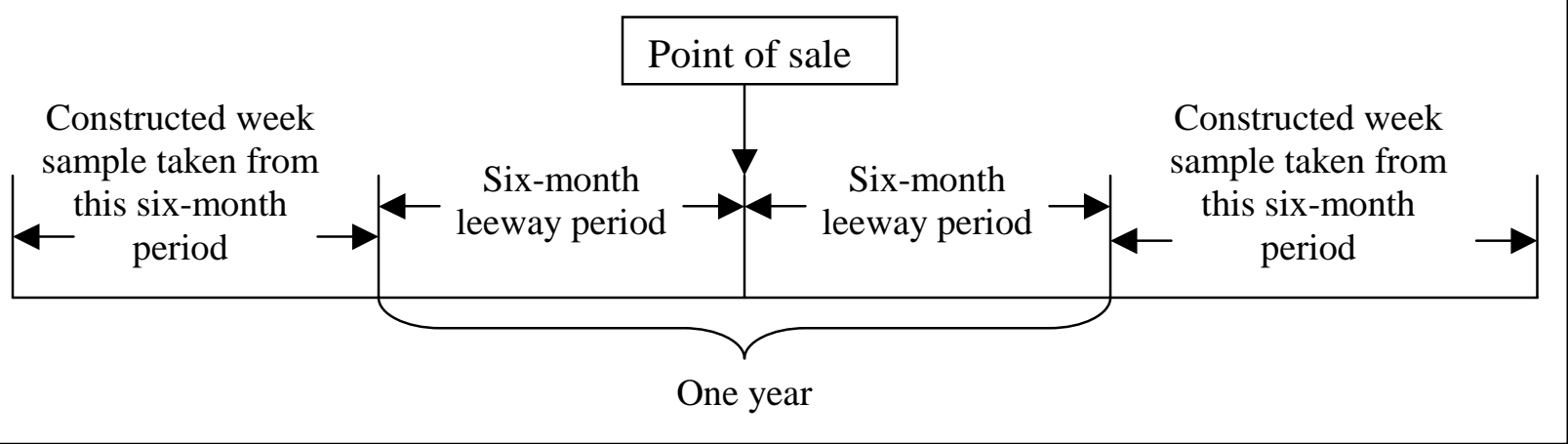

Two constructed one-week samples for each newspaper were chosen, as opposed to random or consecutive day samples, due to information obtained from Riffe, Aust, and Lacy's study of effectiveness in sample methods in newspaper analysis. ${ }^{140}$ They found that constructed week samples produce better estimates than random sampling [emphasis added] because they avoid the possibility of over representing Saturdays or Sundays. ${ }^{141}$ Additionally, the authors point out that although consecutive day [emphasis added] samples are convenient to use, they are not reliable in estimating content for periods of six months or longer. ${ }^{142}$ Overall findings suggested that one constructed week was as efficient as four for a population of six months of editions. ${ }^{143}$ In fact, Riffe, Aust, and Lacy's found that $100 \%$ of the constructed week sample means (compared to $70 \%-85 \%$ for consecutive day and 85\%-95\% for simple random sampling) fell within two standard

140 Daniel Riffe, Charles F. Aust and Stephen R. Lacy, “The Effectiveness of Random, Consecutive Day and Constructed Week Sampling in Newspaper Content Analysis,” Journalism Quarterly 70 (spring 1993): 133-39.
141 Ibid, 139.
142 Ibid.
143 Ibid. 
errors of the population means. ${ }^{144}$

Instead of examining only editorials, or even a combination of editorials and letters to the editor as in Demers' research, ${ }^{145}$ this study focused on the content of the entire editorial page. That is, editorials, letters to the editor, and columns. As mentioned earlier, this is the first known study to consider columns as a part of the editorial page vigor measure.

Editorials and columns were coded for categories derived from Demers’ 1996 study. ${ }^{146}$ The categories include geographic focus, critical evaluation, and origin. Letters to the editor were coded for one category: critical evaluation. Origin was not included since all letters are non-staff. Geographic focus was not coded because, in a pilot study, a single letter often covered several issues affecting more than one region.

Geographic focus of editorials and columns were coded as local or non-local. Both Thrift and Demers applied this category to their research but with different classifications. Dichotomous categories were used as in Demers' study because in a pilot investigation it was difficult to distinguish between state and local foci. It was perhaps even more difficult to determine the difference between national and international foci. In most cases editorials and columns had to be read several times and even then placement was questionable.

A local editorial or column had a main focus that dealt with matters affecting or concerning the community or state in which the newspaper is published. Issues affecting

\footnotetext{
144 Ibid, 138.

145 Demers, “Corporate Newspaper Structure, Editorial Page Vigor, and Social Change,” 857-77.

146 Demers, “Corporate Newspaper Structure, Editorial Page Vigor, and Social Change,” 857-77.
} 
or concerning a community of a bordering state that is a part of a newspaper's primary market were considered local. For example, the Bluefield Daily Telegraph is published in southern West Virginia and has a primary market area that includes Tazewell County, Virginia. An editorial that covered issues affecting Tazewell County was considered local since the newspaper has a major presence in that market. A non-local editorial or column had a main theme that dealt with issues affecting or concerning 1) a city outside the newspaper’s primary circulation area, 2) a U.S. state outside the newspaper's primary circulation area, 3) the U.S. as a whole, 4) a foreign country, or 5) made no reference to a geographic location. Examples of editorial page items lacking a geographic focus include editorials or columns that involved an event or topic, but did not necessarily concern or affect a particular geographic area.

Critical evaluation was composed of whether or not the editorial, letter to the editor, or column was critical or non-critical in the way it evaluated an action, rule, law, decision, position, value, idea, ideology, custom or practice associated with a mainstream individual or group. ${ }^{147}$

An editorial page item was critical if it contained content that was faulting, blaming, censuring or disapproving. ${ }^{148}$ Additionally, if the item's content was presented in a sarcastic or sardonic manner, it was considered critical. If the item consisted of content that was commending, applauding, approving or admiring, or contained content that appeared to be equally balanced, it was coded as non-critical. ${ }^{149}$ Moreover an

\footnotetext{
147 Ibid.

${ }^{148}$ Ibid, 867.

${ }^{149}$ Ibid., 867-8.
} 
editorial page item was coded as non-critical if it contained no reference to a mainstream group, value, etc. ${ }^{150}$

This study followed Demers' definition of mainstream, which is an individual or group associated with local, state, or federal government, the two main political parties, private business and corporations, or mainstream churches. ${ }^{151}$ Two additional groups were added for this analysis: labor, namely coal mining, unions and the individual newspapers under study. Labor unions were considered mainstream because a heavy labor influence was present in West Virginia; it is still today. The northern and southern regions of the state, in particular, were and still are home to many coal mines and coal mining unions.

Individual newspapers were included as mainstream since they are considered an important asset to the communities in which they serve. If an editorial page item was critical or non-critical of the newspaper in which it is printed, the publication was considered a mainstream group. This particular branch of mainstream usually pertains solely to letters to the editor. However, disparagement aimed at other newspapers or the media in general were not included since it is easy to criticize a non-local newspaper or the media in general because they are not in the immediate community or "close to home.”

${ }^{150}$ Ibid. In his initial evaluation, Demers classified critical evaluation as positive, negative, neutral and non-applicable. Due to low intercoder reliability (64\% agreement), he chose to dichotomize the measure into two categories: critical vs. non-critical (negative vs. positive, neutral and non-applicable). This change resulted in a $100 \%$ reliability coefficient.

151 Ibid. Demers' examples of local, state, or federal government include the following: city hall, police, schools, Congress, the President, courts, colleges, mayor, governor, state agencies, city council members, etc. Foreign governments and/or foreign political parties were not considered mainstream in this study. The two main political parties are Democrat and Republican. Mainstream churches include Catholic, mainstream protestant, or Jewish. Christianity, in general, was added in this study as a part of mainstream churches. Private business and corporations are self-explanatory. 
Critical evaluation for editorials, columns and letters to the editor that covered more than one issue was determined according to the dominant theme. That is, the topic with the most devoted column inches.

Another of Demers' coding categories, origin, was used. ${ }^{152}$ However, for this project the author chose to classify the types of origin differently. An editorial item was coded as staff if it was written by someone from the newspaper under study. As with Demers' study, staff classification was determined by either absence of bylines, in the case of editorials, or identifiable staff writer with the presence of a byline. ${ }^{153}$ Editorials and columns that were not written by a staff member, but were submitted by an independent writer exclusively for the newspaper under study, were classified as staff. A second classification of origin, syndicated, was reserved for editorial page items that were obtained from a wire service, syndicates, other newspapers, or sources other than staff. This classification includes syndicated columnists, wire service news stories, and syndicated or "canned" editorials in addition to editorials obtained from other papers. The "canned” editorials and editorials from other newspapers were identified by an editor's note or another acknowledgment stating either the name of the contributing syndicate or the name of the contributing newspaper. Moreover, columns and editorials that were obtained from the non-independent newspapers' wire or news service were coded as syndicated. For example, the Gannett-owned Huntington Herald-Dispatch ran a column that was acquired from the company’s wire service. It was coded as syndicated since it may have run in the chain's other newspapers as well. As mentioned earlier, the

\footnotetext{
${ }^{152}$ Ibid., 868. Demers refers to this category as source in his study.

${ }^{153}$ Ibid.
} 
author chose not to code letters to the editor for origin because all were written by nonstaff. Moreover, origin of letters to the editor was not taken into account for vigor in the current study.

\section{A Note on Editorials and Columns}

At one point, the Associated Press compiled a list of editorials from around the state that was used in some newspapers, especially those without editorial content. For example, the (Keyser) Mineral Daily News-Tribune published editorials pages only a couple of days per week. Only one edition out of the sample published a staff-produced editorial. On other occasions, the newspaper used a list of opinion/editorials from around the state in place of running its own editorials. Since the list was clearly labeled as a compilation of opinion pieces, the items were coded as editorials. However, when other newspapers in the study produced a somewhat similar list without the clear label of “editorials,” they were not coded as editorials. For example, the Raleigh Register ran two pieces entitled, "What Other Papers are Saying,” which included information from papers outside of the state. Since the items were not clearly labeled as opinion pieces and the newspaper already had included its own editorials, the items were not coded as editorials. Moreover, the items were not coded as columns, since they simply consisted of blurbs from other newspapers without clear distinction of the type of piece. Therefore, these items were omitted.

For the purposes of this study the following columns were not considered a factor in the editorial page vigor measure and, therefore, were not included: 1) astrology columns, 2) advice or question and answer columns, 3) quips from Will Rogers, 4) excerpts from novels, short stories, or any other type of literature, and 5) book reviews. 
Some columns seemed to be used as filler or appeared to belong in other sections of the paper and, therefore, were not coded. ${ }^{154}$ For example, the Logan Banner ran an astrology column on their editorial page. The item, which should normally run in the entertainment section, was not coded. For the purposes of this study, it was not appropriate to compare Sydney Omarr’s “Astrocast” to Jack Anderson’s political column in terms of editorial page vigor. Instead the item was omitted from the study.

Another example is Billy Graham’s religious advice column. The researcher believed the column was used on the editorial pages of the Logan Banner and the Beckley Post-Herald solely when they had space to fill. Graham's column, although popular, would have been more appropriately placed on the religion or society pages. In fact, Hynds found that the number of newspapers using religion columnists on the editorial pages declined from 20\% in 1975 to $9 \%$ in $1983 .{ }^{155}$ The drop is because most newspapers have moved this type of column to another section. ${ }^{156}$

The Logan Banner ran a medical advice column entitled, "The Doctor Says.” This column, however, took different forms. Most of the time, the column took a question and answer/advice format. In this case, the column was not coded in terms of editorial page vigor because, as mentioned earlier, advice columns were not considered. Similar to the religion columnists, Hynds found that the number of newspapers using advice columns on the editorial pages declined from $13 \%$ in 1975 to $6 \%$ in $1983 .{ }^{157}$

\footnotetext{
${ }^{154}$ Filler refers to newspaper copy with little or no news value that is used to fill space in a publication.

${ }^{155}$ Hynds, "Editorials, Opinion Pages Still Have Vital Roles at Most Newspapers,” 637.

${ }^{156}$ Ibid.

${ }^{157}$ Ibid.
} 
Again, the decline is due to this type of column being moved to another section. ${ }^{158}$ On a few occasions, “The Doctor Says” took an expository instead of an advice form. That is, it explained an event, situation, or process. In these cases, the column was included.

Short excerpts by Will Rogers were not included in this study. Since the items did not consist of Rogers' column in its entirety, it did not seem appropriate to include and compare to other full-length columns. For example, the Beckley Post-Herald included quips by Will Rogers in more than one issue under examination. All excerpts were selected and edited by a third party and most of the quips, not including the headline and picture, were less than three inches in length. While Will Rogers' full column was important during its time, the shortened selections were not considered suitable items for an editorial page vigor analysis.

Excerpts from short stories or novels were other columns excluded from the study. These pieces were obtained from the author and distributed by Newspaper Enterprise Association. This item is best explained as a “...to be continued” feature. The Logan Banner was the only newspaper in the study that ran this type of column. These columns did not appear in the sample editions once the newspaper changed to nonindependent ownership. Since the excerpts would have been more appropriately placed on the entertainment page and appeared to be used as filler, they were not considered in this editorial page vigor analysis.

The final type of column eliminated from the study was book reviews. Since these articles simply reviewed a piece of literature, comparing them to the most popular 
types of editorial page columns did not make sense. ${ }^{159}$ The Charleston Daily Mail was the lone newspaper to include book reviews on the editorial page: one while under independent ownership and one while under non-independent ownership. While the reviews offer an opinion on a book’s literary quality, it seemed the newspaper was using them as fillers when they ran an op-ed page.

News stories that were placed on the editorial pages were omitted from this editorial page vigor analysis. While this occurrence was rare, it is important to point out for clarification purposes to aid future researchers.

${ }^{159}$ Hynds, “Editors at Most U.S. Dailies See Vital Roles for Editorial Page,” 577-78. In his series of editor surveys, Hynds found the most popular featured editorial page column types were political analysis, political reporting, humorists, guest experts instead of columnists, and business columnists. 


\section{CHAPTER FIVE}

\section{RESULTS}

Two constructed one-week samples from each newspaper yielded a total of 622 editorial page items: 165 editorials, 326 columns, and 131 letters to the editor. Overall, the results suggest no change in editorial vigor when newspapers changed from independent to non-independent ownership. However, vigor in terms of two of the eight hypotheses, geographic focus of editorials and number of letters to the editor, suggest an increase while operating under non-independent ownership.

Hypothesis 1, which suggested the newspapers under independent ownership would publish more staff-written editorials, was rejected. A chi-square test of independence was calculated comparing the frequency of origin for both independent and non-independent ownership. The number of staff-written editorials decreased after the newspaper changed to non-independent ownership, as indicated in Table 1. However, that decrease was not significant $\left(\mathrm{X}^{2}(1)=2.020, \mathrm{p}=.155\right)$. Frequency of staff-produced editorials and type of ownership appear to be independent events and, therefore, suggest no change in editorial vigor. The newspapers, while under non-independent ownership, showed a rise in the number of syndicated editorials. But, again, this amount did not represent a significant increase.

Table 1. Percentages of Editorial Authorship by Ownership

\begin{tabular}{|ll|r|r|}
\hline \multirow{2}{*}{} & \multicolumn{2}{|c|}{ Ownership Situation } \\
\cline { 3 - 4 } & & Family & \multicolumn{1}{c|}{ Chain } \\
\hline Who wrote it & Staff & $88.9 \%$ & $81 \%$ \\
\cline { 2 - 4 } & Syndicated & $11.1 \%$ & $19 \%$ \\
\hline Total & $\mathrm{N}=81$ & $\mathrm{~N}=84$ \\
\hline
\end{tabular}

$X^{2}(1)=2.020, p=.155, N=165$ 
No significant change was detected in the number of staff-written columns leading to a rejection of Hypothesis 2. A chi-square test of independence was calculated comparing the frequency of column origin for both independent and non-independent ownership. Although the number of columns written by staff increased after the newspaper moved to non-independent ownership, as illustrated in Table 2, the finding did not represent a significant difference $\left(\mathrm{X}^{2}(1)=2.274, \mathrm{p}=.132\right)$. Thus, frequency of staffwritten columns and type of ownership appear to be independent events. This finding suggests that there is no significant change in vigor as the newspapers moved from independent to non-independent ownership. And, while the amount of syndicated columns decreased once the newspaper was under non-independent ownership, the change was not large enough to represent a significant finding. Since no significant change was detected, the finding suggests no change in column vigor as the newspapers moved from independent to non-independent ownership.

Table 2. Percentages of Column Authorship by Ownership

\begin{tabular}{|ll|r|r|}
\hline \multirow{2}{*}{ Who wrote it } & \multicolumn{2}{|c|}{ Ownership Situation } \\
\cline { 3 - 4 } & Staff & Family & \multicolumn{1}{c|}{ Chain } \\
\cline { 2 - 4 } & Syndicated & $17.9 \%$ & $24.7 \%$ \\
\hline Total & $82.1 \%$ & $75.3 \%$ \\
\hline
\end{tabular}

$\mathrm{X}^{2}(1)=2.274, \mathrm{p}=.132, \mathrm{~N}=326$

Hypothesis 3, which predicted that under independent ownership the paper would publish more editorials that were critical of mainstream groups, was rejected because no change was detected. A chi-square test of independence was calculated comparing the frequency of critical editorials for both independent and non-independent ownership situations. While the number of critical editorials increased slightly, as indicated in 
Table 3, the rise did not account for a significant change $\left(\mathrm{X}^{2}(1)=.777, \mathrm{p}=.378\right)$.

Frequency of critical editorials and type of ownership appear to be independent events and, therefore, suggest no change in editorial vigor as the newspapers moved from independent to non-independent ownership.

Table 3. Percentages of Editorial Critical Evaluation by Ownership

\begin{tabular}{|ll|r|r|}
\hline \multirow{2}{*}{} & \multicolumn{2}{|c|}{ Ownership Situation } \\
\cline { 3 - 4 } & & \multicolumn{1}{|c|}{ Family } & \multicolumn{1}{c|}{ Chain } \\
\hline Critical Evaluation & Critical & $42 \%$ & $48.8 \%$ \\
\cline { 2 - 4 } & Non-critical & $58 \%$ & $51.2 \%$ \\
\hline Total & & $\mathrm{N}=81$ & $\mathrm{~N}=84$ \\
\hline
\end{tabular}

$\mathrm{X}^{2}(1)=.777, \mathrm{p}=.378, \mathrm{~N}=165$

Hypothesis 4 was rejected. It predicted that the dailies under independent ownership would publish more columns that were critical of mainstream individuals or groups. A chi-square test of independence was calculated comparing the frequency of critical columns for both ownership situations. While the newspapers instead published more critical columns after the purchase by a non-independent, as indicated in Table 4, this change did not represent a significant finding $\left(\mathrm{X}^{2}(1)=.688, \mathrm{p}=.407\right)$. Therefore, frequency of critical columns and type of ownership appear to be independent events. Hence, this finding suggests no change in column vigor.

Table 4. Percentages of Column Critical Evaluation by Ownership

\begin{tabular}{|ll|r|r|}
\hline \multirow{2}{*}{ Critical Evaluation } & \multicolumn{2}{|c|}{ Ownership Situation } \\
\cline { 3 - 4 } & Critical & Family & \multicolumn{1}{c|}{ Chain } \\
\cline { 2 - 4 } & Non-critical & $21.4 \%$ & $25.3 \%$ \\
\hline Total & & $\mathrm{N}=16.6 \%$ & $74.7 \%$ \\
\hline
\end{tabular}

$X^{2}(1)=.688, p=.407, N=326$ 
Hypothesis 5, which predicted that the dailies under independent ownership would publish more locally focused editorial, was rejected. A chi-square test of independence was calculated comparing the frequency of editorials concerning local issues for both independent and non-independent ownership situations. After the purchase by a non-independent, the number of locally focused editorials increased, as illustrated in Table 5, and a significant interaction was found $\left(\mathrm{X}^{2}(1)=4.547, \mathrm{p}=.033\right)$. After moving to non-independent ownership, the newspapers were more likely to publish locally focused editorials than while under independent ownership. As a result, an increase in vigor, in terms of geographic focus of editorials, was detected.

Table 5. Percentages of Editorial Focus by Ownership

\begin{tabular}{|ll|r|r|}
\hline \multirow{2}{*}{} & \multicolumn{2}{|c|}{ Ownership Situation } \\
\cline { 3 - 4 } & \multicolumn{1}{|c|}{ Family } & \multicolumn{1}{c|}{ Chain } \\
\hline Geographic Focus & Local & $37 \%$ & $53.6 \%$ \\
\cline { 2 - 4 } & Non-local & $63 \%$ & $46.4 \%$ \\
\hline Total & $\mathrm{N}=81$ & $\mathrm{~N}=84$ \\
\hline
\end{tabular}

$X^{2}(1)=4.547, p=.033, N=165$

Hypothesis 6 was rejected because no significant change was detected. The hypothesis predicted that while under independent ownership, the dailies would publish more columns focused on local issues. A chi-square test of independence was calculated comparing the frequency of locally focused columns and type of ownership situation. While the number of columns concerning local issues increased after the purchase by a non-independent, the margin of change was not significant $\left(\mathrm{X}^{2}(1)=2.913, \mathrm{p}=.088\right)$, as shown in Table 6. Therefore, frequency of locally focused columns and type of ownership situation appear to be independent events; they do not reflect a change in vigor. 
Table 6. Percentages of Column Focus by Ownership

\begin{tabular}{|ll|r|r|}
\hline \multirow{2}{*}{} & \multicolumn{2}{|c|}{ Ownership Situation } \\
\cline { 3 - 4 } & & Family & \multicolumn{1}{c|}{ Chain } \\
\hline Geographic Focus & Local & $14.3 \%$ & $21.5 \%$ \\
\cline { 2 - 4 } & Non-local & $85.7 \%$ & $78.5 \%$ \\
\hline Total & & $\mathrm{N}=168$ & $\mathrm{~N}=158$ \\
\hline
\end{tabular}

$\mathrm{X}^{2}(1)=2.913, p=.088, N=326$

Hypothesis 7, which predicted that while under independent ownership the dailies would publish more letters to the editor, was rejected. As Table 7 illustrates, the newspapers published 56 letters while under independent ownership as compared to 75 after moving to non-independent ownership, an increase of 34\%. This finding indicates that the newspapers exhibited a higher commitment to printing their readers' letters after, not before, the change to non-independent ownership, which, in turn, suggests an increase in vigor.

A significant change was not detected in the number of letters to the editor that were critical of mainstream individuals or groups, which led to a rejection of Hypothesis 8. A chi-square test of independence was calculated comparing the frequency of critical letters to the editor and type of ownership situation. As Table 7 demonstrates, the newspapers published slightly more critical letters to the editor while under independent ownership, but the number did not account for a significant difference $\left(\mathrm{X}^{2}(1)=.053, \mathrm{p}=\right.$ .818). As a result, frequency of critical columns and type of ownership appear to be independent events. Therefore, no marked change in vigor was detected. 
Table 7. Percentages of Letter Critical Evaluation by Ownership

\begin{tabular}{|ll|r|r|}
\hline \multirow{2}{*}{} & \multicolumn{2}{|c|}{ Ownership Situation } \\
\cline { 3 - 4 } & & Family & \multicolumn{1}{c|}{ Chain } \\
\hline \multirow{2}{*}{ Critical Evaluation } & Critical & $44.6 \%$ & $46.7 \%$ \\
\cline { 2 - 4 } & Non-critical & $55.4 \%$ & $53.3 \%$ \\
\hline Total & $\mathrm{N}=56$ & $\mathrm{~N}=75$ \\
\hline
\end{tabular}

$X^{2}(1)=.053, p=.818, N=131$

\section{A Look at the Individual Newspapers}

When reviewed individually, most newspapers in the study exhibited similar results as the overall findings. However, there were some exceptions. Since, when broken down to individual newspapers, the sample sizes for each editorial page item were greatly reduced, the results of the chi-square tests for independence were difficult to generalize and were sometimes inappropriate. For some cases, the Fischer's Exact Test was more suitable in determining significance than the chi-square approximation. In those cases where one or more cells contained expected frequencies of five or less, the Fischer's Exact Test was used. This test provides a more accurate significance reading in 2 X 2 tables with low sample sizes.

Table 8. Beckley Post-Herald Summary Values

\begin{tabular}{|llllr|}
\hline Category & Item & $\mathbf{X}^{2}$ Value & df & Significance \\
\hline Origin & Editorials & Fischer's Exact Test & & 1.000 \\
\cline { 2 - 5 } Critical Evaluation & Columns & 0.093 & 1 & 0.760 \\
& & & & 1.000 \\
\cline { 2 - 5 } & Editorials & Fischer's Exact Test & & 0.398 \\
\cline { 2 - 5 } Geographic Focus & Columns & 0.715 & 1 & 1.000 \\
\cline { 2 - 5 } & Letters & Fischer's Exact Test & & 0.537 \\
\cline { 2 - 5 } & Editorial & 0.381 & 1 & 0.967 \\
\cline { 2 - 5 }
\end{tabular}

Editorials: $\mathrm{N}=23$, Columns: $\mathrm{N}=72$, Letters: $\mathrm{N}=10$ 
The Beckley Post-Herald, which was owned by the Hodel family and purchased by Clay Communications, overall showed no significant changes in terms of editorial page vigor and ownership situation, as indicated in Table 8. When applied to each of this study's hypotheses, the frequency of item types and categories and the type of ownership situation appear to be independent events.

While operating under the independent ownership of the Hodel family, the Beckley Post-Herald published three letters to the editor. After moving to the nonindependent ownership of Clay Communications, the paper published seven letters, an increase of $133 \%$. This finding indicates that the chain owners showed a higher commitment of publishing their reader's letters (rejection of Hypothesis 7) than the independent owners, which suggests and increase in vigor like that of the overall study.

The newspaper differed from the overall analysis regarding geographic focus of editorials (Hypothesis 5), however. While vigor increased in total sample in terms of locally focused editorials, the Beckley Post-Herald exhibited no significant change $\left(\mathrm{X}^{2}(1)\right.$ $=.381, \mathrm{p}=.537)$, as indicated in Table 8 . This indicates no change in vigor in terms of geographic focus of editorials.

Table 9. Bluefield Daily Telegraph Summary Values

\begin{tabular}{|lllrr|}
\hline Category & Item & $\mathbf{X}^{\mathbf{2}}$ Value & df & Significance \\
\hline Origin & Editorials & & & $*$ \\
\cline { 2 - 5 } Critical Evaluation & Columns & Fischer's Exact Test & & 0.088 \\
& & & & 0.406 \\
\cline { 2 - 5 } & Editorials & Fischer's Exact Test & 1 & 0.942 \\
\cline { 2 - 5 } Geographic Focus & Columns & 0.005 & 1 & 0.319 \\
\cline { 2 - 5 } & Letters & 0.991 & & $.022^{* *}$ \\
\cline { 2 - 5 } & Editorials & Fischer's Exact Test & & 0.088 \\
\hline
\end{tabular}

Editorials: $\mathrm{N}=20$, Columns: $\mathrm{N}=37$, Letters: $\mathrm{N}=38$

* No statistics were computed because Origin is a constant; all editorials were staff-written.

** Significant at the .05 level. 
The Bluefield Daily Telegraph showed different results. As illustrated in Table 9, geographic focus of editorials yielded a significant change (Fischer's $\mathrm{p}=.022$ ). A closer look at the data in Table 10 suggest that editorial vigor, in terms of geographic focus of editorials, increased after the paper was purchased by Worrell Newspapers based out of Virginia. In fact, while under independent ownership, the Bluefield Daily Telegraph published only two editorials that were focused on local issues as compared to seven while under non-independent ownership; an increase of $250 \%$. As a result, the newspaper reduced the number of non-local editorials by $77 \%$ after the purchase by Worrell Newspapers.

Table 10. Percentages of Editorial Focus by Ownership

\begin{tabular}{|ll|r|r|}
\hline \multirow{2}{*}{} & \multicolumn{2}{|c|}{$\begin{array}{c}\text { Bluefield Daily Telegraph } \\
\text { Ownership Situation }\end{array}$} \\
\cline { 3 - 4 } & Family & Chain \\
\hline \multirow{2}{*}{ Geographic Focus } & Local & $18.2 \%$ & $77.8 \%$ \\
\cline { 2 - 4 } & Non-local & $81.8 \%$ & $22.2 \%$ \\
\hline Total & & $\mathrm{N}=11$ & $\mathrm{~N}=9$ \\
\hline
\end{tabular}

Significant at the .05 level, $N=20$

The findings from this newspaper, then, fall in line with the results of the overall analysis. That is, instead of publishing more locally focused editorials under independent ownership, as predicted in Hypothesis 5, the Bluefield Daily Telegraph published more locally focused editorials after moving to non-independent ownership. However, since the sample size of the individual paper is so small, the results are difficult to generalize. Researchers must use caution when reporting findings of a small sample $(\mathrm{N}=20)$, such as that of the Bluefield Daily Telegraph's editorials. To obtain a broader view of the individual newspaper, a larger sample should be examined. 
The individual analysis of the newspaper indicates a different finding regarding number of letters to the editor (Hypothesis 7) when compared to the overall sample. While under the ownership of the Shott family, the newspaper published 23 letters as compared to 15 under the ownership of the Worrell chain; a 35\% decrease. This finding, then, suggests a decrease in vigor, in terms of the Bluefield Daily Telegraph's number of letters to the editor, after the change to a non-independent. Critical evaluation of the letters (Hypothesis 8) showed no significant change $\left(\mathrm{X}^{2}(1)=.991, \mathrm{p}=.319\right)$, as illustrated in Table 9, which was similar to the overall analysis.

Table 11. Charleston Daily Mail Summary Values

\begin{tabular}{|c|c|c|c|c|}
\hline Category & Item & $\mathrm{X}^{2}$ Value & df & Significance \\
\hline Origin & Editorials & & & * \\
\hline Critical Evaluation & Columns & Fischer's Exact Test & & 0.661 \\
\hline \multirow{5}{*}{ Geographic Focus } & Editorials & 0.433 & 1 & 0.510 \\
\hline & Columns & Fischer's Exact Test & & 0.628 \\
\hline & Letters & 2.84 & 1 & 0.092 \\
\hline & Editorials & 4.739 & 1 & $0.029 * \star$ \\
\hline & Columns & Fischer's Exact Test & & 0.302 \\
\hline
\end{tabular}

Editorials: $\mathrm{N}=30$, Columns: $\mathrm{N}=26$, Letters: $\mathrm{N}=58$

* No statistics were computed because Origin is a constant; all editorials were staff-written.

** Significant at the .05 level

The Charleston Daily Mail, which was owned by the Clay family and sold to the Thomson chain, shadowed the results of the overall analysis. As shown in Table 11, geographic focus of editorials produced a significant change $\left(\mathrm{X}^{2}(1)=4.739, \mathrm{p}=.029\right)$. While under the operation of the Clay family, six of the 14 , or $42.9 \%$, editorials were focused on local issues, as illustrated in Table 12. After changing to non-independent ownership, that number increased to $81.3 \%, 13$ of 16 , which indicates an increase of 117\%. As a result, the Charleston Daily Mail decreased the number of editorials focused 
on non-local issues by $62.5 \%$, from eight of 14 to three of 16 , after moving to Thomson ownership, as indicated in Table 12.

Table 12. Percentages of Editorial Focus by Ownership

\begin{tabular}{|ll|r|r|}
\hline \multirow{2}{*}{} & \multicolumn{2}{|c|}{$\begin{array}{c}\text { Charleston Daily Mail } \\
\text { Ownership Situation }\end{array}$} \\
\cline { 3 - 4 } & Family & \multicolumn{1}{c|}{ Chain } \\
\hline \multirow{2}{*}{ Geographic Focus } & Local & $42.9 \%$ & $81.3 \%$ \\
\cline { 2 - 4 } & Non-local & $57.1 \%$ & $18.8 \%$ \\
\hline Total & & $\mathrm{N}=14$ & $\mathrm{~N}=16$ \\
\hline
\end{tabular}

Significant at the .05 level, $N=30$

The data suggest, then, that the individual analysis falls in line with the overall findings of an increase in editorial page vigor, in terms of geographic focus of editorials (Hypothesis 5), after the paper was purchased by the Thomson chain. Since the sample size of the individual analysis is relatively small $(\mathrm{N}=30)$, a larger sample of the Charleston Daily Mail's editorials should be examined before generalizing this change.

Letters to the editor also produced similar findings as overall analysis. While under independent ownership, the newspaper published 17 letters to the editor. After moving to non-independent ownership, that number climbed to 41 ; an increase of $141 \%$. Therefore, vigor, in terms of number of letters to the editor (Hypothesis 7), increased as in the overall analysis. As illustrated in Table 11, critical evaluation of the letters (Hypothesis 8), however, produced no significant results $\left(X^{2}(1)=2.84, p=.092\right)$ similar to the overall analysis. 
Table 13. Huntington Herald Dispatch Summary Values

\begin{tabular}{|lllrr|}
\hline Category & Item & $\mathbf{X}^{2}$ Value & df & Significance \\
\hline Origin & & & \\
& Editorials & & & * \\
\cline { 2 - 5 } Critical Evaluation & Columns & Fischer's Exact Test & & 0.428 \\
& & & 1 & 0.705 \\
& Editorials & 0.144 & 1 & 0.419 \\
\cline { 2 - 5 } & Columns & 0.653 & & 1.000 \\
\cline { 2 - 5 } Geographic Focus & Letters & Fischer's Exact Test & \\
& & & 1 & $.049^{\star \star}$ \\
& Editorials & 3.877 & & 1.000 \\
\hline
\end{tabular}

Editorials: $\mathrm{N}=28$, Columns: $\mathrm{N}=64$, Letters: $\mathrm{N}=11$

* No statistics were computed because Origin is a constant; all editorials were staff-written.

** Significant at the .05 level.

The Huntington Herald-Dispatch was similar to the overall findings. As indicated in Table 13, geographic focus of editorials yielded a marginally significant change ( $\mathrm{X}^{2}(1)$ $=3.877, \mathrm{p}=.049)$. A closer look at the data in Table 14 suggests that editorial vigor, in terms of geographic focus of editorials, increased after the paper was purchased by Gannett. In fact, while under independent ownership, six editorials were focused on local issues as compared to 10 under non-independent ownership; an increase of $67 \%$. Moreover, the number of non-local editorials decreased by $67 \%$, from nine to three, after the newspaper began operating under Gannett. Since the significance level is only marginal $(\mathrm{p}=.049)$ and the sample size of the individual paper is small $(\mathrm{N}=28)$, the results should not be generalized until an expanded analysis, including more editions, is conducted. 
Table 14. Percentages of Editorial Focus by Ownership

\begin{tabular}{|ll|r|r|}
\hline \multirow{2}{*}{} & \multicolumn{2}{|c|}{$\begin{array}{c}\text { Huntington Herald-Dispatch } \\
\text { Ownership Situation }\end{array}$} \\
\cline { 3 - 4 } & \multicolumn{2}{|c|}{ Family } & \multicolumn{1}{c|}{ Chain } \\
\hline Geographic Focus & Local & $40 \%$ & $76.9 \%$ \\
\cline { 2 - 4 } & Non-local & $60 \%$ & $23.1 \%$ \\
\hline Total & $\mathrm{N}=15$ & $\mathrm{~N}=13$ \\
\hline
\end{tabular}

Significant at the .05 level, $N=28$

The number of letters to the editor (Hypothesis 7) increased slightly after Gannett's purchase. While the number of letters increased only by one, $20 \%$, it falls in line with the overall analysis' findings, which suggests an increase in vigor. Critical evaluation of letters (Hypothesis 8 ) produced no marked findings (Fischer’s $\mathrm{p}=1.00$ ), as indicated in Table 13, which falls in line with the overall analysis.

Table 15. (Keyser) Mineral Daily News-Tribune Summary Values

\begin{tabular}{|c|c|c|c|}
\hline Category & Item & $\mathrm{X}^{2}$ Value & Significance \\
\hline \multicolumn{4}{|l|}{ Origin } \\
\hline & Editorials & Fischer's Exact Test & 1.000 \\
\hline \multicolumn{4}{|c|}{ Fischer's Exact Test } \\
\hline & Editorials & Fischer's Exact Test & 1.000 \\
\hline & Columns & Fischer's Exact Test & 1.000 \\
\hline & Letters & Fischer's Exact Test & 1.000 \\
\hline \multicolumn{4}{|l|}{ Geographic Focus } \\
\hline & Columns & Fischer's Exact Test & 1.000 \\
\hline
\end{tabular}

Editorials: $\mathrm{N}=6$, Columns: $\mathrm{N}=9$, Letters: $\mathrm{N}=7$

* No statistics were computed because Geographic Focus is a constant; all editorials were locally focused.

The Mineral Daily News-Tribune, which was owned by the Tetrick family and purchased by the Liberty Group, overall showed no significant changes in terms of editorial page vigor and ownership situation, as indicated in Table 15. When applied to each of this study's hypotheses, the frequency of item types and categories and the type of ownership situation appear to be independent events. 
While operating under the independent ownership of the Tetrick family, the Mineral Daily News-Tribune published three letters to the editor. After moving to the non-independent ownership of the Liberty Group, the paper published four letters, a slight increase which falls in line with the overall findings (rejection of Hypothesis 7). Moreover, critical evaluation of letters (Hypothesis 8) produced no marked findings (Fischer's $\mathrm{p}=1.00$ ), as indicated in Table 15, which shadows the overall analysis.

The newspaper differed from the overall analysis regarding geographic focus of editorials (Hypothesis 5), however, because no change was detected. In fact, all of the editorials in the study were locally focused, which suggests no change in vigor after the paper moved from independent to non-independent ownership.

Table 16. Logan Banner Summary Values

\begin{tabular}{|c|c|c|c|}
\hline Category & Item & $\mathrm{X}^{2}$ Value & Significance \\
\hline \multicolumn{4}{|l|}{ Origin } \\
\hline \multicolumn{4}{|l|}{ Critical Evaluation } \\
\hline CMilical Evaluadion & Editorials & Fischer's Exact Test & 1.000 \\
\hline & Columns & Fischer's Exact Test & 0.607 \\
\hline & Letters & Fischer's Exact Test & 0.250 \\
\hline \multicolumn{2}{|l|}{ Geographic Focus } & Fischer's Exact Test & 0.498 \\
\hline & Columns & Fischer's Exact Test & 1.000 \\
\hline
\end{tabular}

Editorials: $\mathrm{N}=29$, Columns: $\mathrm{N}=43$, Letters: $\mathrm{N}=4$

*** Significant at the .001 level

The Logan Banner’s individual examination produced different findings than the overall analysis. Critical evaluation and geographic focus of the editorial page items showed insignificant results when compared to the different ownership situations, as illustrated in Table 16. However, origin of editorials produced strongly significant findings (Fischer's $\mathrm{p}=.001$ ). While under the independent ownership of the Frey family, all 12 of the editorials in the sample were written by staff members, as indicated 
in Table 17. After changing to non-independent ownership, however, less than half were staff produced. This finding shows a $42 \%$ decline in the number of staff-written editorials after the newspaper was sold to a non-independent. Moreover, 10 of the 17 editorials, almost $60 \%$, of the editorials were syndicated. Thus, editorial vigor of the Logan Banner, in terms of authorship of editorials (Hypothesis 1), decreased after the family sold the paper.

\section{Table 17. Percentages of Editorial Authorship by Ownership}

\begin{tabular}{|ll|c|c|}
\hline \multirow{2}{*}{} & \multicolumn{2}{|c|}{$\begin{array}{c}\text { Logan Banner Ownership } \\
\text { Situation }\end{array}$} \\
\cline { 3 - 4 } & \multicolumn{2}{|c|}{ Family } & \multicolumn{1}{c|}{ Chain } \\
\hline \multirow{2}{*}{ Who wrote it } & Staff & $100 \%$ & $41.2 \%$ \\
\cline { 2 - 4 } & Syndicated & & $58.8 \%$ \\
\hline Total & $\mathrm{N}=12$ & $\mathrm{~N}=17$ \\
\hline
\end{tabular}

Significant at the .001 level, $\mathrm{N}=29$

Number of letters to the editor also differed from the overall analysis. The Logan Banner published three letters while under independent ownership and only one after the change to a non-independent. This finding indicates a decrease in vigor, in terms of number of letters to the editor (acceptance of Hypothesis 7), after the paper moved to non-independent ownership, which is the opposite of the overall analysis. As indicated in Table 16, critical evaluation of the letters, however, produced insignificant results (Fischer's $\mathrm{p}=.250$ ) similar to the overall findings. Since the sample of letters is small, caution should be taken before making generalizations based upon this individual analysis. 
Table 18. Raleigh Register Summary Values

\begin{tabular}{|lllll|}
\hline Category & Item & $\mathbf{X}^{2}$ Value & df & Significance \\
\hline Origin & Editorials & Fischer's Exact Test & & \\
& Columns & 0.226 & 1 & 0.215 \\
\cline { 2 - 5 } Critical Evaluation & & 1 & 0.634 \\
& Editorials & 0.279 & 1 & 0.597 \\
\cline { 2 - 5 } & Columns & 0.004 & & 0.952 \\
\cline { 2 - 5 } Geographic Focus & Letters & & 1 & 0.550 \\
& & & 1 & 0.258 \\
& Editorials & 0.358 & & \\
\cline { 2 - 5 } & Columns & 1.277 & 1 & \\
\end{tabular}

Editorials: $\mathrm{N}=29$, Columns: $\mathrm{N}=75$, Letters: $\mathrm{N}=3$

* No statistics were computed because Critical Evaluation is a constant; all letters to the editor were non-critical.

The Raleigh Register, which was owned by the Hodel family and later merged with the neighboring Beckley Post-Herald, overall showed no significant changes in terms of editorial page vigor and ownership situation, as indicated in Table 18. When applied to each of this study's hypotheses, the frequency of item types and categories and the type of ownership situation appear to be independent events.

While operating under the independent ownership of the Hodel family, the Raleigh Register published two letters to the editor. After moving to the non-independent ownership of Clay Communications, the paper published only one letter, a slight decrease. This finding suggests a decrease in vigor, in terms of number of letters (acceptance of Hypothesis 7), after the paper switched to non-independent ownership. However, since the sample size is small $(\mathrm{N}=3)$ not much validation should be applied to the results. The finding differs from the overall analysis of number of letters, which indicated an increase in vigor.

The newspaper differed from the overall analysis regarding geographic focus of editorials (Hypothesis 5). While vigor increased in the total sample in terms of locally 
focused editorials, the Raleigh Register exhibited no significant change $\left(X^{2}(1)=.358, p=\right.$ .550), as indicated in Table 18. This finding suggests no change in vigor in terms of geographic focus of editorials. 


\section{CHAPTER SIX}

\section{DISCUSSION}

Overall, editorial page vigor showed no change as the newspapers under study moved from independent to non-independent ownership. The data rejected nearly all of the hypotheses, which predicted that the newspapers would exhibit more vigor while under family ownership. No significant change was detected in authorship of editorials or columns; critical evaluation of editorials, columns, or letters to the editor; or geographic focus of columns as the newspapers moved from independent to nonindependent ownership. Thus, when applied to the research question, the findings suggest no overall change in product quality due to concentration of ownership. However, two hypotheses concerning geographic focus of editorials and number of letters to the editor were rejected because an increase in vigor was detected.

The first significant finding was that of editorial geographic focus. The number of editorials focused on issues affecting the newspapers’ local or state community increased by 50\%, indicating an increase in vigor as the newspapers moved from independent to non-independent ownership. Simultaneously, the newspapers decreased the number of editorials focused on non-local issues by 23.5\%. This finding, then, conflicts with Thrift's research on West Coast dailies, which found that newspapers published fewer aggressive editorials on local matters after the purchase by a chain. ${ }^{160}$ The current study's results suggest that the newspapers exhibited a higher commitment to local issues while under non-independent ownership rather than independent ownership as predicted in the hypothesis. An explanation of the finding could be that the non-

${ }^{160}$ Thrift, "How Chain Ownership Affects Editorial Vigor,” 329. 
independents wanted to demonstrate to their communities that they were concerned with issues in the area, not just national or international news. Since non-independents are sometimes viewed as disregarding local coverage, they may have wanted to ensure their readers that this would not happen once they took over operation of the newspapers.

With the Federal Communications Commission’s (FCC) June 2003 proposed relaxed limits on media ownership, research signifying its possible effects on news product is vital now more than ever. The decision, if implemented, could raise the national television ownership limit from 35\% to $45 \%{ }^{161}$ This would allow a single company "to own the daily newspaper, several television stations and up to eight radio stations in the same community," according to an article by editorial page editor of The Capital Times, John Nichols. ${ }^{162}$ Critics of the proposal fear that it could decrease the amount of local news coverage in these communities. This study, however, suggests otherwise. As mentioned previously, instead of publishing less locally focused editorials under the ownership of a chain, the West Virginia newspapers in this analysis printed significantly more. Although this examination provides only a snapshot of editorial pages in a small state over an almost 35 year time span, it is important because it helps shed more light on one of the most highly debated issues concerning the FCC's proposal. The study also demonstrates a need for further research in how concentration of ownership affects radio and television, as well as newspapers.

161 www.fcc.gov/ownership/, Accessed on April 8, 2004.

162 John Nichols, “John Nichols: Cronkite Fears the Media Mergers Threaten Democracy,” www.madison.com/captimes/opinion/column/nichols/60744.php, Accessed on April 9, 2004. 
Another significant finding was in number of letters to the editor. While under non-independent ownership, the newspapers published more letters, not less, as predicted in the hypothesis. This finding suggests that the newspapers were more dedicated to their readers by publishing their opinions after the non-independents took over. Since nonindependents are sometimes unfamiliar with the areas in which they are situated, they most likely feel more comfortable publishing letters, whether critical or non-critical, of issues affecting their community. This is perhaps because the readers might have a better awareness of their area’s events than the non-independent owners. Independents, on the other hand, may feel they know their communities well enough to report on the issues themselves. Furthermore, the independent owners in this study may have had ties to mainstream individuals within the area and were reluctant to publish certain letters that could have offended them.

A strength of the study is the comparative analysis over two time periods of ownership as in Thrift's research. Examining editorial pages while under independent ownership and then comparing them to editorial pages under non-independent operation provides a better picture of the changes in vigor, if any, than examining the chain pages alone. Future studies should include a control group of a few West Virginia dailies that has remained independent. This addition will be useful for comparison purposes and should increase the significance of the study's findings.

Another strength of the study was the inclusion of columns. As previously mentioned, this is the first known study to incorporate editorial page columns in addition to editorials and letters to the editor. While findings on columns yielded mostly insignificant results in this study, they indicate a need for future research with a much 
larger sample. Columns are important to include in editorial page vigor studies because oftentimes the issues and the opinions of the columnists have the ability to affect readers' views.

Another suggestion for future research would be to include editorial cartoons in addition to the other editorial page items in the study. As with columns, the cartoons depict images of opinion that could portray the newspapers' views. This inclusion will help provide an even broader understanding of editorial page vigor under both ownership situations.

One weakness of the study was the sample size of each editorial page item.

Future research should either expand the study to include 1) more West Virginia newspapers that changed from non-independent ownership, 2) newspapers from similar areas of the United States, and/or 3) a four-week constructed sample: two weeks before the change of ownership and two weeks after. Including any of the above suggestions should only increase the significance of the present findings regarding geographic focus of editorials and number of letters to the editor. Additionally, expanding the sample size could possibly produce significant results in the other areas discussed in the hypotheses as well.

An additional issue in the study worth mentioning deals with the Charleston Daily Mail, which is a part of the state's only JOA. The newspaper partners with the state's largest newspaper in terms of circulation, the family-owned Charleston Gazette. While the Charleston Daily Mail followed the same trends as the overall study, the effects of media ownership on editorial vigor of JOA newspapers cannot be determined since its partner paper was not examined. A separate future research project should examine this 
unique situation within West Virginia and compare it to JOA newspapers of similar ownership situations, one chain-owned and one family-owned, in other regions.

More research is needed on media concentration of ownership's effects on editorial page vigor so broader generalizations can be made. The inclusion of columns as an editorial page item will only strengthen any case involving vigor. Only then can it be determined if media concentration of ownership has had a detrimental effect on the heart of daily newspapers: the editorial page. 
Appendix I: Newspaper and sampling information

Following is information regarding sell dates, leeway periods, sample periods, sample dates, and ownership information of the West Virginia dailies included in this study.

The leeway periods are six months before the change in ownership and six months after the change of ownership: a one-year period total. The leeway period before the change of ownership is the 182 days prior to, and not including, the sell date. The leeway period after the change of ownership is 182 days after, and including, the sell date. The sample periods are 183 days prior to the beginning of the leeway period and 183 days after the end of the one-year leeway period. The sample dates were chosen using a constructed week sampling method, which was explained in the methods section.

\section{Beckley Post-Herald}

Independent owner: The Hodel family

Sell date: July 1, 1976

Non-independent owner: Clay Communications, Inc.

Leeway period before: January 1, 1976 to June 30, 1976

Leeway period after: July 1, 1976 to December 29, 1976

Sample period before: July 2, 1975 to December 31, 1975

Sample period after: December 30, 1976 to June 30, 1977

Sample dates independent: Monday, August 4, 1975; Tuesday, December 9, 1975;

Wednesday, August 6, 1975; Thursday, July 3, 1975; Friday, October 10, 1975; Saturday, October 4, 1975; Sunday, December 7, 1975

Sample dates non-independent: Monday, May 30, 1977; Tuesday, June 7, 1977; Wednesday, April 27, 1977; Thursday, February 10, 1977; Friday, June 10, 1977; Saturday, April 9, 1977; Sunday, May 1, 1977

Notes: The Beckley Post-Herald collaborated with the Raleigh Register for the Saturday and Sunday editions under both independent and non-independent ownership. The paper also collaborated with the Raleigh Register for Memorial Day on the Monday under nonindependent ownership. The data for these dates were used for both the Beckley PostHerald and the Raleigh Register. The two papers later merged to form the Beckley Register-Herald, which is still in existence today.

\section{Bluefield Daily Telegraph}

Independent owner: The Shott family 
Sell date: January 1, 1985

Non-independent owner: Worrell Newspapers, Inc.

Leeway period before: July 3, 1984 to December 31, 1984

Leeway period after: January 1, 1985 to July 1, 1985

Sample period before: January 2, 1984 to July 2, 1984

Sample period after: July 2, 1985 to December 31, 1985

Sample dates independent: Monday, June 18, 1984; Tuesday, February 14, 1984;

Wednesday, January 4, 1984; Thursday, March 22, 1984; Friday, March 30, 1984;

Saturday, June 16, 1984; Sunday, May 27, 1984

Sample dates non-independent: Monday, October 28, 1985; Tuesday, December 31, 1985; Wednesday, October 9, 1985; Thursday, October 24, 1985; Friday, October 11, 1985; Saturday, November 2, 1985; Sunday, October 13, 1985

Notes: None

\section{Charleston Daily Mail}

Independent owner: The Clay family

Sell date: April 16, 1987

Non-independent owner: Thomson Newspapers

Leeway period before: October 16, 1986 to April 15, 1987

Leeway period after: April 16, 1987 to October 14, 1987

Sample period before: April 16, 1986 to October 15, 1986

Sample period after: October 15, 1987 to April 14, 1988

Sample dates independent: Monday, June 9, 1986; Tuesday, May 27, 1986; Wednesday, September 24, 1986; Thursday, September 4, 1986; Friday, May 30, 1986; Saturday, October 11, 1986

Sample dates non-independent: Monday, December 21, 1987; Tuesday, March 15, 1988; Wednesday, February 24, 1988; Thursday, February 18, 1988; Friday, March 25, 1988; Saturday, January 30, 1988 
Notes: The Charleston Gazette, a family owned paper, and the Charleston Daily Mail formed a JOA in $1957 .{ }^{163}$ The jointly owned agency, Charleston Newspapers, is run by an independent president and general manager, who reports to a management committee comprising two representatives from each paper. ${ }^{164}$ The two newspapers collaborate on the Sunday edition called the Gazette-Mail. Since the Gazette contributes the editorial material for this edition, the Daily Mail was not coded for Sundays in this study.

\section{Huntington Herald-Dispatch}

Independent owner: The Long family

Sell date: November 1, 1971

Non-independent owner: Gannett

Leeway period before: May 3, 1971 to October 31, 1971

Leeway period after: November 1, 1971 to April 30, 1972

Sample period before: November 1, 1970 to May 2, 1971

Sample period after: May 1, 1972 to October 30, 1972

Sample dates independent: Monday, December 7, 1970; Tuesday, April 27, 1971;

Wednesday, April 14, 1971; Thursday, December 24, 1970; Friday, January 15, 1971;

Saturday, November 14, 1970; Sunday, April 25, 1971

Sample dates non-independent: Monday, October 16, 1972; Tuesday, May 23, 1972; Wednesday, May 24, 1972; Thursday, June 1, 1972; Friday, May 19, 1972; Saturday, June 10, 1972; Sunday, September 24, 1972

Notes: The Huntington Publishing Company was purchased by the Honolulu Star Bulletin, a non-independent, on January 25, 1971. However, since the Star Bulletin owned the paper for less than one year, the leeway periods and sample were taken from the Gannett purchase date. The newspaper was still under Gannett ownership at the time of this study. The Huntington Herald-Dispatch collaborated with the now dissolved (Huntington) Advertiser on Saturday and Sunday editions, which were coded for the study.

163 “12 Cities Still Have JOAs: Court-approved Joint Operating Agreements Down from Over 25.” http://seattlepi.nwsource.com/business/119679_joaelsewhere29.html, Accessed on March 30, 2004.

164 Steve Fidel, “Singleton, MediaNews Group are No Strangers to the JOA Environment.” http://deseretnews.com/dn/view/0,1249,230013835,00.html, Accessed on March 30, 2004. 


\section{(Keyser) Mineral Daily News-Tribune}

Independent owner: The Tetrick family

Sell date: December 9, 1998

Non-independent owner: Liberty Group Publishing

Leeway period before: June 10, 1998 to December 8, 1998

Leeway period after: December 9, 1998 to June 8, 1999

Sample period before: December 9, 1997 to June 9, 1998

Sample period after: June 9, 1999 to December 8, 1999

Sample dates independent: Wednesday, January 21, 1998; Saturday, March 21, 1998

Sample dates independent that were pulled but had no editorial page: Monday, April 20, 1998; Tuesday, March 24, 1998; Thursday, May 21, 1998; Friday, December 12, 1997

Sample dates non-independent: Monday, August 23, 1999; Wednesday, June 23, 1999; Saturday, November 6, 1999

Sample dates non-independent that were pulled but had no editorial page: Tuesday, August 3, 1999; Thursday, October 28, 1999; Friday, June 25, 1999

Notes: The Mineral News-Tribune collaborated with the Mountain Echo, a weekly paper, for the Saturday edition. The newspaper did not publish a Sunday edition.

\section{$\underline{\text { Logan Banner }}$}

Independent owner: The Frey family

Sell date: October 1, 1965

Non-independent owner: Group publisher, Tutt Bradford, out of Maryville, TN

Leeway period before: April 2, 1965 to September 30, 1965

Leeway period after: October 1, 1965 to March 31, 1966

Sample period before: October 1, 1964 to April 1, 1965

Sample period after: April 1, 1966 to September 30, 1966 
Sample dates independent: Monday, November 23, 1964; Tuesday, October 27, 1964;

Wednesday, February 17, 1965; Thursday, December 24, 1964; Friday, October 9, 1964;

Saturday, February 13, 1965

Sample dates non-independent: Monday, April 18, 1966; Tuesday, August 23, 1966;

Wednesday, September 21, 1966; Thursday, August 4, 1966; Friday, April 8, 1966;

Saturday, May 21, 1966

Notes: The newspaper did not publish a Sunday edition at the time of this study.

\section{$\underline{\text { Raleigh Register }}$}

Independent owner: The Hodel family

Sell date: July 1, 1976

Non-independent owner: Clay Communications, Inc.

Leeway period before: January 1, 1976 to June 30, 1976

Leeway period after: July 1, 1976 to December 29, 1976

Sample period before: July 2, 1975 to December 31, 1975

Sample period after: December 30, 1976 to June 30, 1977

Sample dates independent: Monday, July 21, 1975; Tuesday, September 16, 1975;

Wednesday, October 29, 1975; Thursday, November 6, 1975; Friday, October 10, 1975;

Saturday, October 4, 1975; Sunday, December 7, 1975

Sample dates non-independent: Monday, May 30, 1977; Tuesday, January 11, 1977;

Wednesday, March 23, 1977; Thursday, February 10, 1977; Friday, April 22, 1977;

Saturday, April 9, 1977; Sunday, May 1, 1977

Notes: The Raleigh Register collaborated with the Beckley Post-Herald for the Saturday and Sunday editions under both independent and non-independent ownership. The paper also collaborated with the Beckley Post-Herald for Memorial Day on the Monday under non-independent ownership. The data for these dates were used for both the Raleigh Register and the Beckley Post-Herald. The Raleigh Register is no longer a sole publication. Since a portion of the paper is still in existence today as a part of the Beckley Register-Herald, it was included in the study. 
Appendix II: Newspaper item citations

\section{Beckley Post-Herald}

\section{Independent}

Note: Saturday, October 4, 1975 and Sunday, December 7, 1975 are also cited under Raleigh Register since they collaborated on these dates.

\section{Editorials}

“Back to the Jungle?” (Beckley) Post-Herald and (Raleigh) Register, 7 December 1975, 6.

“Coal Conversion is Important Step.” Beckley Post-Herald, 4 August 1975, 4.

“Energy Bill Politics Putrid; Veto Needed.” Wall Street Journal as reprinted in the Beckley Post-Herald, 9 December 1975, 4.

“Ford Administration to Focus on Crime.” Beckley Post-Herald, Beckley Post-Herald, 3 July 1975, 4.

“Indira Gandhi Wins ‘Adolph Hitler Title’.” Beckley Post-Herald, 3 July 1975, 4.

“Is He Off the Dime?” (Beckley) Post-Herald and (Raleigh) Register, 7 December 1975, 6.

“Make the Right Change.” (Beckley) Post-Herald and (Raleigh) Register, 7 December 1975, 6.

“Lack of Natural Gas Could be a Hoax.” Beckley Post-Herald, 10 October 1975, 4.

“Leadership Lacking in Special Session.” Beckley Post-Herald, 6 August 1975, 4.

“Soviet’s Grain Need Raises Questions.” Beckley Post-Herald, 4 August 1975, 4.

“Speed Deaths Down, How Justify Hike?” (Beckley) Post-Herald and (Raleigh) Register, 4 October 1975, 6.

\section{Columns}

Anderson, Jack. “Civil Rights Leader Smear Target of FBI.” Beckley Post-Herald, 10 October 1975, 4.

. “Errors in FBI Transcripts Questionable.” Beckley Post-Herald, 4 August 1975, 4. 
. “Goons, Guns, Gold Used to Win Election.” Beckley Post-Herald, 3 July 1975, 4.

. “Gossip of ‘Harem’ Upsets Speaker Albert.” Beckley Post-Herald, 9

December 1975, 4.

. “Nixon Not Involved with Wounded Knee.” (Beckley) Post-Herald and (Raleigh) Register, 4 October 1975, 6.

. "'Tis the Season to be Wary: Some Pointers." (Beckley) Post-Herald and (Raleigh) Register, 7 December 1975, 6.

. "Will Give Ford Tape to Buckley on PBS.” Beckley Post-Herald, 6 August 1975, 4.

Baker, Russell. “Observer: Your Clothes Tell Me...” (Beckley) Post-Herald and (Raleigh) Register, 7 December 1975, 6.

Benson, George. “Sharp Trading Communists Have Dealt U.S. Out of Oil.” Beckley Post-Herald, 10 October 1975, 4.

Donnelly, Shirley. “Construction of C\&O Tremendous Job.” Beckley Post-Herald, 4 August 1975, 4.

. “Peanut Sitting on a Railroad Track---.” Beckley Post-Herald, 6 August 1975, 4.

. "Yesterday and Today: Alderson Man First College Educated Baptist Minister.” Beckley Post-Herald, 9 December 1975, 4.

. "Yesterday and Today: Exiled Native Yearns for the Mountains.” Beckley Post-Herald, 3 July 1975, 4.

. "Yesterday and Today: Manson Left a String of Crimes Behind.” (Beckley) Post-Herald and (Raleigh) Register, 4 October 1975, 6.

. "Yesterday and Today: West Virginia Bananas Taste the Best.” Beckley PostHerald, 10 October 1975, 4.

Hodel, Emile J. “Top O’ the Morning: Historical Items Still Welcome.” Beckley PostHerald, 6 August 1975, 4.

. “Top O’ the Morning: Imagine 77 Years of Wedded Bliss!” Beckley PostHerald, 3 July 1975, 4. 
. “Top O’ the Morning: Sarandon Praised for Film Role.” (Beckley) PostHerald and (Raleigh) Register, 4 October 1975, 6.

. “Top O’ the Morning: Toy Fund Pushes Near \$2,400.” Beckley PostHerald, 9 December 1975, 4.

. “Top O’ the Morning: Welcome Reaction from Ford!” Beckley PostHerald, 10 October 1975, 4.

Hodel, John. "Bug Dust: Meaning, Understanding Are Most Important!” (Beckley) PostHerald and (Raleigh) Register, 7 December 1975, 6.

Kohler, Saul. “The Presidency: Campaigning is Tough All but Jimmy.” (Beckley) PostHerald and (Raleigh) Register, 7 December 1975, 6.

Landau, Jack C. "The Law Column: Press, Public Have Stake in Mandel Case.” (Beckley) Post-Herald and (Raleigh) Register, 7 December 1975, 7.

Lisagor, Peter. "Not America’s Bag: Ford's China Trip Meaningless.” (Beckley) PostHerald and (Raleigh) Register, 7 December 1975, 7.

Reston, James. “Cheer Up! Things are Terrible.” (Beckley) Post-Herald and (Raleigh) Register, 7 December 1975, 7.

Sulzberger, C.L. "Foreign Affairs: Brazil: An Elephant in the Bed.” (Beckley) PostHerald and (Raleigh) Register, 7 December 1975, 7.

Tully, Andrew. "Cruelty to Vice Presidents is Nothing New to Politics." Beckley Post Herald, 4 August 1975, 4.

. "Ford Should Use Moynihan as Expert on Urban Affairs.” Beckley PostHerald, 9 December 1975, 4.

. "Heroic Acts are Forgotten; Freaks Get the Applause.” (Beckley) Post- Herald and (Raleigh) Register, 4 October 1975, 6.

. "Inflation is Built in by Weaselly Congress." Beckley Post-Herald, 6 August 1975, 4

. “Special Type of Man Needed to Celebrate 'Independence'.” Beckley PostHerald, 3 July 1975, 4.

Wicker, Tom. "In the Nation: Power and Corruption." (Beckley) Post-Herald and (Raleigh) Register, 7 December 1975, 7. 
Woodrum, Gene L. “Top O’ the Morning: Banks of Streams Filled with Litter.” Beckley Post-Herald, 4 August 1975, 4.

\section{Letters}

Lenzie, Richard. “Christian Virtues Defeated.” Beckley Post-Herald, 3 July 1975, 4.

Smith, Larry O. “Seeks Mail.” (Beckley) Post-Herald and (Raleigh) Register, 7 December 1975, 7.

Watkins, James H. “New River Fund Goal Met; Battle Still On.” (Beckley) Post-Herald and (Raleigh) Register, 7 December 1975, 7.

\section{Non-independent}

Note: Monday, May 30, 1977, Saturday, April 9, 1977 and Sunday, May 1, 1977 are also cited under Raleigh Register since they collaborated on these dates.

\section{Editorials}

“Alcoholics Omitted.” Beckley Post-Herald, 7 June 1977, 4.

"Carter Not Same as When Elected." Richmond Times-Dispatch as reprinted in the Beckley Post-Herald, 10 June 1977, 4.

“Cuba Recognition is Hollow Move.” Beckley Post-Herald, 7 June 1977, 4.

“Don’t Cheer Yet.” (Beckley) Post-Herald and (Raleigh) Register, 9 April 1977, 4.

“GOP Asks Answers.” Beckley Post-Herald, 27 April 1977, 4.

“Governor’s Image Suffering Greatly.” Beckley Post-Herald, 27 April 1977, 4.

“Pet Owners Conned.” (Beckley) Post-Herald and (Raleigh) Register, 9 April 1977, 4.

“Singlaub’s Views Interest Solons.” (Beckley) Post-Herald and (Raleigh) Register, 30 May 1977, 4.

“So What!” (Beckley) Post-Herald and (Raleigh) Register, 9 April 1977, 4.

“Teacher Alliance is Back for More.” Beckley Post-Herald, 10 February 1977, 4.

“Uneasy Over Belgrade.” (Beckley) Post-Herald and (Raleigh) Register, 30 May 1977, 4.

“Young Too Erratic for U.N. Position.” (Beckley) Post-Herald and (Raleigh) Register, 9 April 1977, 4. 


\section{Columns}

Amick, Dorothy. "Bug Dust: Martin Luther Bragg: An Old Friend.” (Beckley) PostHerald and (Raleigh) Register, 9 April 1977, 4.

Anderson, David E. "Religion in America: Slowing 'Mergers'.” (Beckley) Post-Herald and (Raleigh) Register, 9 April 1977, 4.

Anderson, Jack. "Fears of Inflation Grow.” (Beckley) Post-Herald and (Raleigh) Register, 9 April 1977, 4.

. "Human Rights Fight Means: U.S. Must Cut Ties with Dictators.” (Beckley) Post-Herald and (Raleigh) Register, 9 April 1977, 4.

. “Justices Only Human.” Beckley Post-Herald, 10 June 1977, 4.

. “Nixon Delays Show.” Beckley Post-Herald, 10 February 1977, 4.

. “Nixon Wanted Pardon.” Beckley Post-Herald, 7 June 1977, 4.

. “’People’s’ President?” Beckley Post-Herald, 27 April 1977, 4.

. "Rifle Association Caught in Backfire.” (Beckley) Post-Herald and (Raleigh) Register, 30 May 1977, 4.

Baker, Russell. “Observer: Lunch of Champions.” (Beckley) Post-Herald and (Raleigh) Register, 9 April 1977, 4.

Benson, George. “Industry Can Get Job Done.” Beckley Post-Herald, 10 June 1977, 4.

. “U.S. Tax Unbearable.” Beckley Post-Herald, 10 February 1977, 5.

Donnelly, Shirley. “Yesterday and Today: Death Took Two Landmarks.” Beckley PostHerald, 10 June 1977, 4.

. "Yesterday and Today: Heating Future Homes Uncertain.” Beckley PostHerald, 10 February 1977, 4.

. "Yesterday and Today: Historic Rosary on Bedpost.” Beckley Post-Herald, 27 April 1977, 4.

. "Yesterday and Today: Jones Story Living Legend---I." (Beckley) PostHerald and (Raleigh) Register, 30 May 1977, 4.

. "Yesterday and Today: Lived Under 17 Presidents.” Beckley Post-Herald, 7 June 1977, 4. 
. "Yesterday and Today: Other Kinds of Graveyard.” (Beckley) Post-Herald and (Raleigh) Register, 9 April 1977, 4.

Grimes, Richard. “Memos Found Most Revealing.” Beckley Post-Herald, 7 June 1977, 4. . “Not Fitting for Tax Relief.” Beckley Post-Herald, 10 June 1977, 4.

Hall, Mike. "Views from the Staff: Predisposed to Violence and Death.” Beckley PostHerald, 30 May 1977, 4.

Harrigan, Anthony. "President Bows to Pressure.” (Beckley) Post-Herald and (Raleigh) Register, 30 May 1977, 4.

Hodel, Emile J. “Top O’ the Morning: Dinner Brings \$300, 000 for WVU.” (Beckley) Post-Herald and (Raleigh) Register, 9 April 1977, 4. . “Top O' the Morning: Keeping up with Lawmaking Hard.” Beckley PostHerald, 27 April 1977, 4.

. “Top O’ the Morning: We Would Give Toward Gold Dome.” Beckley PostHerald, 10 February 1977, 4.

Hoppe, Arthur. “The Innocent Bystander: Wife Talk.” (Beckley) Post-Herald and (Raleigh) Register, 9 April 1977, 4.

Kohler, Saul. “The Presidency: The First 100 Days.” (Beckley) Post-Herald and (Raleigh) Register, 9 April 1977, 4.

Landau, Jack C. “The Law Column: Spanking.” (Beckley) Post-Herald and (Raleigh) Register, 9 April 1977, 4.

Lewis, Anthony. “Abroad at Home: Signs of Change.” (Beckley) Post-Herald and (Raleigh) Register, 9 April 1977, 4.

Peck, Harry. “Pecknically Speaking: Myles of Pleasure.” (Beckley) Post-Herald and (Raleigh) Register, 9 April 1977, 4.

Reston, James. “Where are we Going?” (Beckley) Post-Herald and (Raleigh) Register, 9 April 1977, 4.

Safire, William. “Essay: Equal Justice under Leak.” (Beckley) Post-Herald and (Raleigh) Register, 9 April 1977, 4.

Tully, Andrew. “Ambassador is Big Problem.” Beckley Post-Herald, 7 June 1977, 4. 
4.

. “Carter-Mondale \& Co. Crybabies.” Beckley Post-Herald, 27 April 1977,

. “General's Firing in Order.” (Beckley) Post-Herald and (Raleigh)

Register, 30 May 1977, 4.

. “President Can Only Dream.” Beckley Post-Herald, 10 February 1977, 4.

. “U.S. Stand Perplexes Russians.” (Beckley) Post-Herald and (Raleigh)

Register, 9 April 1977, 4.

Woodrum, Gene L. “Views from the Staff: Dictator Demanding Admiration?” Beckley Post-Herald, 10 June 1977, 4.

. "Views from the Staff: Graduates’ Future Much Better.” Beckley Post-Herald, 7 June 1977, 4.

\section{Letters}

Anderson, Lacy. "Public Indebted to Media.” Beckley Post-Herald, 10 February 1977, 5.

Farley, R.L. “Necessary Action.” (Beckley) Post-Herald and (Raleigh) Register, 9 April 1977, 4.

Lilly, W.L. “Of Fools and Crooks.” Beckley Post-Herald, 10 February 1977, 5.

Palmer, Alfred. “U.S. Should Keep Canal.” Beckley Post-Herald, 10 February 1977, 5.

Tilley, Randall. “Asks Shelter in Oceana.” Beckley Post-Herald, 10 February 1977, 5.

Tuckwiller, L.J. “Capital Warning.” Beckley Post-Herald, 10 February 1977, 5.

Webster, Rhue J., Sr. “Refutes Prior Letter.” Beckley Post-Herald, 10 February 1977, 5.

\section{Bluefield Daily Telegraph}

\section{Independent}

\section{Editorials}

“Accuser Accused.” Bluefield Daily Telegraph, 16 June 1984, 4.

“A Hopeful Sign, Maybe.” Bluefield Daily Telegraph, 14 February 1984, 4.

“The Jackson Mission.” Bluefield Daily Telegraph, 4 January 1984, 4. 
“A Kennedy Clone?” Bluefield Daily Telegraph, 30 March 1984, 4.

“Khadafy Again.” Bluefield Daily Telegraph, 14 February 1984, 4.

“Long Strike Inevitable?” Bluefield Daily Telegraph, 27 May 1984, 4A.

“The Low Road Again.” Bluefield Daily Telegraph, 22 March 1984, 4.

“Our Troubled Youngsters.” Bluefield Daily Telegraph, 22 March 1984, 4.

“Reagan Did Well.” Bluefield Daily Telegraph, 18 June 1984, 4.

“Strange Rules.” Bluefield Daily Telegraph, 16 June 1984, 4.

“Those Subs.” Bluefield Daily Telegraph, 27 May 1984, 4A.

\section{Columns}

Anderson, Jack. “Alaskan Paper Mills Seek Special Favors.” Bluefield Daily Telegraph, 16 June 1984, 4.

. “DeLorean Drama to Unfold Soon.” Bluefield Daily Telegraph, 30 March 1984, 4.

. "Document Shows Fear of Recession.” Bluefield Daily Telegraph, 22 March 1984, 4.

. “Portillo’s Fortune Mexico’s Misfortune.” Bluefield Daily Telegraph, 18 June 1984, 4.

. "Slush Fund Found in El Salvador.” Bluefield Daily Telegraph, 14 February 1984, 4.

. “Strange Feud in Manila.” Bluefield Daily Telegraph, 4 January 1984, 4.

Buckley, William F. “An Ambassador to the Vatican?” Bluefield Daily Telegraph, 30 March 1984, 4.

“Memo to Gary.” Bluefield Daily Telegraph, 18 June 1984, 4.

“On Pre-Empting the Categories.” Bluefield Daily Telegraph, 16 June 1984, 4.

"Remembering the JFK Campaign.” Bluefield Daily Telegraph, 22 March 1984, 4. 
Evans, M. Stanton. “Reagan Generous and Correct.” Bluefield Daily Telegraph, 4 January 1984, 4.

Graff, Donald F. “’Dead-End Dollars’ Don’t Help.” Bluefield Daily Telegraph, 14 February 1984, 4.

Harvey, Paul. “Another 1983 Audit.” Bluefield Daily Telegraph, 30 March 1984, 4. . “Captain Bob.” Bluefield Daily Telegraph, 16 June 1984, 4.

. “Off-Price Retailing.” Bluefield Daily Telegraph, 22 March 1984, 4.

. “Where is Freedom for Conservatives?” Bluefield Daily Telegraph, 4 January 1984, 4.

Lambro, Donald. “Taxpayers Subsidize Special Interest Projects.” Bluefield Daily Telegraph, 30 March 1984, 4.

Rusher, William. “What Comes Next?” Bluefield Daily Telegraph, 16 June 1984, 4.

Tiede, Tom. “There is a Place Colder than Bluefield.” Bluefield Daily Telegraph, 4 January 1984, 4.

Will, George F. “Koch’s Book 'Mayor’ on Best Seller List.” Bluefield Daily Telegraph, 22 March 1984, 4.

\section{Letters}

Bailey, Richard Douglas. “New Party Needed.” Bluefield Daily Telegraph, 18 June 1984, 4.

Brown, Carolyn. “Teacher Praised.” Bluefield Daily Telegraph, 18 June 1984, 4.

Cahill, J. “Stay Closed.” Bluefield Daily Telegraph, 27 May 1984, 4A.

Candill, Eugene F. “Ethical Demise.” Bluefield Daily Telegraph, 27 May 1984, 4A.

Comer, Henry L. “Support Vets.” Bluefield Daily Telegraph, 27 May 1984, 4A.

Crumpecker, G.H. “Elect the PSC.” Bluefield Daily Telegraph, 14 February 1984, 4.

Daniel, John S. “Boucher Blasted.” Bluefield Daily Telegraph, 27 May 1984, 4A.

Dillon, Pat. “Remember Vets.” Bluefield Daily Telegraph, 27 May 1984, 4A.

Ewen, Lynda Ann. “Water Action.” Bluefield Daily Telegraph, 27 May 1984, 4A. 
Hamilton, Donna. “For the Blue Law.” Bluefield Daily Telegraph, 27 May 1984, 4A.

Hunt, Rosie. “Litter Problem.” Bluefield Daily Telegraph, 27 May 1984, 4A.

“Keep Squire Open.” Bluefield Daily Telegraph, 27 May 1984, 4A.

Kupje, Donald. “No War Needed.” Bluefield Daily Telegraph, 27 May 1984, 4A.

Maddox, Roy. “Bigoted Editorial.” Bluefield Daily Telegraph, 14 February 1984, 4.

McGowan, W.J. “Christian Rights.” Bluefield Daily Telegraph, 18 June 1984, 4.

Pack, David C. “Column Critic.” Bluefield Daily Telegraph, 18 June 1984, 4.

Phipps, F.R. “Deport the Numbskulls.” Bluefield Daily Telegraph, 27 May 1984, 4A.

Pingley, Michael. “BHS Praises BSC.” Bluefield Daily Telegraph, 18 June 1984, 4.

Smith, Grace P. “Chandler Praised.” Bluefield Daily Telegraph, 27 May 1984, 4A.

Spencer, John S., Jr. “Neal’s Nails.” Bluefield Daily Telegraph, 27 May 1984, 4A.

Stickel, Rebecca S. “Defending BSC.” Bluefield Daily Telegraph, 14 February 1984, 4.

Thompson, J. Spencer. “Asinine Movement.” Bluefield Daily Telegraph, 27 May 1984, $4 \mathrm{~A}$.

Wimmer, Debbie. “K-Mart Right.” Bluefield Daily Telegraph, 27 May 1984, 4A.

\section{Non-Independent}

\section{Editorials}

“Bible Classes Issue Drags on.” Bluefield Daily Telegraph, 13 October 1985, E6.

“Bible Classes Opinion Unclear.” Bluefield Daily Telegraph, 2 November 1985, A1.

“Board Decision a Curious One.” Bluefield Daily Telegraph, 9 October 1985, A4.

“How Many Lives are Enough?” Bluefield Daily Telegraph, 11 October 1985, A4.

“Hosni Mubarak Should Apologize.” Bluefield Daily Telegraph, 24 October 1985, A4.

“The Proposed Charter Change.” Bluefield Daily Telegraph, 31 December 1985, A4.

“Sportsmanship Abounds.” Bluefield Daily Telegraph, 24 October 1985, A4. 
“Sweeping Neely Under the Rug.” Bluefield Daily Telegraph, 2 November 1985, A4.

“The United Way Needs Your Help.” Bluefield Daily Telegraph, 28 October 1985, A4.

\section{Columns}

Baker, Russell. “Inferiority the Story of Life.” Bluefield Daily Telegraph, 11 October 1985, A4.

Buckley, William. “Afterstorm Thoughts on Gloria.” Bluefield Daily Telegraph, 9 October 1985, A4. E6.

. “Gorbachev Strategy to Divide.” Bluefield Daily Telegraph, 13 October 1985,

Hawkins, Barbara. “Memorial Building Considered.” Bluefield Daily Telegraph, 24 October 1985, A4.

. “Princeton Magistrate Revenues.” Bluefield Daily Telegraph, 28 October 1985, A4.

Lewis, Anthony. “Apartheid Policies Unchanged.” Bluefield Daily Telegraph, 2 November 1985, A4.

. “Immigrants Face Harsh Treatment.” Bluefield Daily Telegraph, 31

December 1985, A4.

Lewis, Flora. “Arms Limit Verification is a Must.” Bluefield Daily Telegraph, 31 December 1985, A4.

Pedneau, Dave. “School Board Owes Minister Apology.” Bluefield Daily Telegraph, 2 November 1985, A4.

Reston, James. “Canadian Trade Worthwhile.” Bluefield Daily Telegraph, 11 October 1985, A4.

Rosenthal, Andrew. “Embassy Ready, but Israelis are Not.” Bluefield Daily Telegraph, 31 December 1985, A4.

Rothberg, Donald M. “Should President be Held to Two Terms?” Bluefield Daily Telegraph, 11 October 1985, A4.

Safire, William. "Publicity Boomerang of Policy.” Bluefield Daily Telegraph, 9 October 1985, A4. 
E6.

Wicker, Tom. “ABM Treaty Subverted, Interpreted.” Bluefield Daily Telegraph, 28 October 1985, A4.

. “Nicaragua: Should we Intervene?” Bluefield Daily Telegraph, 24 October 1985, A4.

Will, George. “Reagan’s Fresh Start Not So Clear.” Bluefield Daily Telegraph, 2 November 1985, A4.

\section{Letters}

Blevins, Duane A., Mary F. Sadler, William J. Sadler, and Jeffrey F. St. Clair. "More about Bible Classes.” Bluefield Daily Telegraph, 9 October 1985, A4.

Blevins, Vangie. “Hunter Responds.” Bluefield Daily Telegraph, 28 October 1985, A4.

Brock, Garland T. “More Theology.” Bluefield Daily Telegraph, 13 October 1985, E6.

Brown, Lee. “World Community?” Bluefield Daily Telegraph, 24 October 1985, A4.

Conner, Donna. “Thanks for Paper.” Bluefield Daily Telegraph, 24 October 1985, A4.

Denham, Chuck. “BHS Band Commended.” Bluefield Daily Telegraph, 9 October 1985, A4.

Harman, Roy S. “Air Traffic.” Bluefield Daily Telegraph, 24 October 1985, A4.

Hurst, Mickey Z. “On Hunting.” Bluefield Daily Telegraph, 28 October 1985, A4.

Lister, Rosemary. “Evolution vs. Creationism.” Bluefield Daily Telegraph, 24 October 1985, A4.

Mitchell, Harold. “Nuclear War.” Bluefield Daily Telegraph, 11 October 1985, A4.

“Mr. Bailey Appreciated.” Bluefield Daily Telegraph, 9 October 1985, A4.

Mulholland, Dale. “'Live Aid’ Criticized.” Bluefield Daily Telegraph, 13 October 1985, E6.

Phillips, M. “More Parking Inequities.” Bluefield Daily Telegraph, 28 October 1985, A4.

Richmond, Syneetra. “An Opinion.” Bluefield Daily Telegraph, 13 October 1985, E6. 
Steele, Barbara. “Support Bible Class.” Bluefield Daily Telegraph, 9 October 1985, A4.

\section{Charleston Daily Mail}

\section{Independent}

\section{Editorials}

“Fast Fat.” Charleston Daily Mail, 24 September 1986, 4A.

“Free Daniloff.” Charleston Daily Mail, 24 September 1986, 4A.

“Hyping Crime.” Charleston Daily Mail, 11 October 1986, 4A.

“Kanawha Schools.” Charleston Daily Mail, 27 May 1986, 4A.

“Odds \& Ends.” Charleston Daily Mail, 30 May 1986, 4A.

“Odds \& Ends.” Charleston Daily Mail, 9 June 1986, 6A.

“Odds \& Ends.” Charleston Daily Mail, 24 September 1986, 4A.

“Public Service.” Charleston Daily Mail, 4 September 1986, 4A.

“Rules of Combat.” Charleston Daily Mail, 4 September 1986, 4A.

“Social Security.” Charleston Daily Mail, 30 May 1986, 4A.

“The Tax Bill.” Charleston Daily Mail, 9 June 1986, 6A.

“Teachers Colleges.” Charleston Daily Mail, 27 May 1986, 4A.

“Trade Bill.” Charleston Daily Mail, 30 May 1986, 4A.

“Welfare Reform.” Charleston Daily Mail, 11 October 1986, 4A.

\section{Columns}

Anderson, L.T. “Ending Hypocrisy in Sports Competition.” Charleston Daily Mail, 24 September 1986, 4A.

. "Sullivan Would Smile at Censorship by the Methodists." Charleston Daily Mail, 30 May 1986, 5A.

Broder, David S. “Teacher Aides Would Improve Education.” Charleston Daily Mail, 30 May 1986, 4A. 
. “Three Good Reasons to Vote Republican.” Charleston Daily Mail, 27 May 1986, 4A.

Gaziano, Rosalie. “Israel, the Land that Cradled Man’s Concept of a Caring God.” Charleston Daily Mail, 24 September 1986, 5A.

Goodman, Allan E. Goodman. "Intelligence Agencies Should be Given a Comprehensive Charter.” Charleston Daily Mail, 30 May 1986, 5A.

Goodman, Ellen. “Stay-at-Homes Don’t Need to Apologize.” Charleston Daily Mail, 9 June 1986, 6A.

. "Women Just a Sidebar in Harvard History." Charleston Daily Mail, 4 September 1986, 4A.

Kilpatrick, James J. “Another Smarmy Exercise in Poverty Chic.” Charleston Daily Mail, 30 May 1986, 4A.

. “Cartoons, Mud Pies and Federal Budgets.” Charleston Daily Mail, 24

September 1986, 4A.

. "Despite the Guff, Insurance Crisis is Real.” Charleston Daily Mail, 9 June 1986, 6A.

Kimelman, John. “Wise and Sharp Make for a Lively Race.” Charleston Daily Mail, 24 September 1986, 5A.

Rooney, Andy. “Too Many Americans Settle For.” Charleston Daily Mail, 11 October 1986, 4A.

Royko, Mike. “Let’s Try to Find Dan Rather’s Frequency.” Charleston Daily Mail, 11 October 1986, 4A.

. “Prison isn’t Like a Trip to Disney World.” Charleston Daily Mail, 4 September 1986, 4A.

Sommer, Jeff. “The Obstacles on the Road to an Arms Control Pact.” Charleston Daily Mail, 24 September 1986, 5A.

Will, George F. “Can Any Racial Policy Be Constitutional?” Charleston Daily Mail, 27 May 1986, 4A.

\section{Letters}

Anderson, Bob T. “S.C. Firemen Saved Lives.” Charleston Daily Mail, 27 May 1986, $4 \mathrm{~A}$. 
Bridgette, Ed. “Presumption Ruled in Neary Trial.” Charleston Daily Mail, 30 May 1986, $5 \mathrm{~A}$.

Camp, Charles. “Apartheid Needs Alternate Solutions.” Charleston Daily Mail, 30 May 1986, 4A.

Coffman, C. Keith. “Elections are Like Horse Races.” Charleston Daily Mail, 30 May 1986, 4A.

Eskew, Jim. “Company’s Donation Was Appreciated.” Charleston Daily Mail, 9 June 1986, 6A.

Garrett, Larry D. "Why are Soviets Not Condemned?” Charleston Daily Mail, 30 May 1986, 4A.

Hampton, Ann H. “Regatta Crowds Surpassed Estimates.” Charleston Daily Mail, 24 September 1986, 4A.

Henson, Sam, M.D. “Will Lawyers Cap Their Income?” Charleston Daily Mail, 9 June 1986, 6A.

Hoffman, Edwin. “Commissioners are Irresponsible.” Charleston Daily Mail, 4 September 1986, 4A.

Hudson, Walter J. “Hill People Control Charleston.” Charleston Daily Mail, 30 May 1986, 5A.

Lowther, Frank D. “Casinos Could Raise Crime Rate.” Charleston Daily Mail, 27 May 1986, 4A.

Mahoney, E.M. “New Medicare Act Will Improve Care.” Charleston Daily Mail, 24 September 1986, 4A.

McClanahan, Keith. “Buffalo Salutes Coach Ferrari.” Charleston Daily Mail, 27 May 1986, 4A.

Ross, Frances C. “Gold Dome Symbolizes Hope.” Charleston Daily Mail, 30 May 1986, 5 A.

Ryan, Nancy J. “Study on Mothers was Misunderstood.” Charleston Daily Mail, 24 September 1986, 4A.

Walker, Mrs. Jerry. "Veterans Deserve to be Recognized.” Charleston Daily Mail, 30 May 1986, 5A. 
Webb, Elmer E. “Government Caters to the Rich.” Charleston Daily Mail, 4 September 1986, 4A.

\section{Non-independent}

\section{Editorials}

“Blue Flu.” Charleston Daily Mail, 25 March 1988, 4A.

“Camp Dawson.” Charleston Daily Mail, 25 March 1988, 4A.

“Congress’ Pay.” Charleston Daily Mail, 15 March 1988, 4A.

“CURA Battle.” Charleston Daily Mail, 18 February 1988, 4A.

“Hayes West.” Charleston Daily Mail, 21 December 1987, 4A.

“Incumbents.” Charleston Daily Mail, 25 March 1988, 4A.

“Levy Bribe.” Charleston Daily Mail, 30 January 1988, 4A.

“Medicaid Tax.” Charleston Daily Mail, 18 February 1988, 4A.

“Mexico.” Charleston Daily Mail, 18 February 1988, 4A.

“Regatta.” Charleston Daily Mail, 24 February 1988, 4A.

“Seniority.” Charleston Daily Mail, 15 March 1988, 4A.

“Tax and Tax.” Charleston Daily Mail, 21 December 1987, 4A.

“Tax Laws.” Charleston Daily Mail, 24 February 1988, 4A.

“Test Scores.” Charleston Daily Mail, 30 January 1988, 4A.

“The Deficit.” Charleston Daily Mail, 15 March 1988, 4A.

“Turnpike.” Charleston Daily Mail, 24 February 1988, 4A.

\section{Columns}

Anderson, L.T. “West Virginia’s Contributions to the Language.” Charleston Daily Mail, 25 March 1988, 5A.

. "Why has Candidate McGraw Cooled it?” Charleston Daily Mail, 24

February 1988, 4A. 
Conine, Ernest. “Voters Don’t Want What Candidates Should Offer.” Charleston Daily Mail, 18 February 1988, 5A.

Grimes, Richard. “Judge Cook’s Decision Drawing Flak.” Charleston Daily Mail, 15 March 1988, 4A.

Kilpatrick, James. "Regarding Ollie North and the Law.” Charleston Daily Mail, 25 March 1988, 4A.

Rooney, Andy. "The Olympics are about Performance, Not Politics.” Charleston Daily Mail, 24 February 1988, 5A.

. "Settling in for Another Super Bowl.” Charleston Daily Mail, 30 January 1988, 4A.

Royko, Mike. “A Little Cultural Misunderstanding.” Charleston Daily Mail, 18 February 1988, 4A.

Will, George. “Democrats May Have the Last Laugh.” Charleston Daily Mail, 21 December 1987, 4A.

\section{Letters}

Ahmad, Dirar. “Cut Aid to Israel to Help Palestinians.” Charleston Daily Mail, 25 March 1988, 5A.

Beane Gravely, Melissa D. “Bridge Repair Needed as Help to 16 Families.” Charleston Daily Mail, 30 January 1988, 4A.

Berry, Myrtle. “Seniors Suffer from Bureaucracy.” Charleston Daily Mail, 24 February 1988, 5A.

Brown, Patrick H., III. “Exemption Legally Keeps CURA Reports Confidential.” Charleston Daily Mail, 24 February 1988, 4A.

Butterworth, J. Scott. “DNR License Increase Will Save Sport Areas.” Charleston Daily Mail, 24 February 1988, 5A.

Cendana, Elena. “Brent Galyean’s Death was a Shocking Loss to Many.” Charleston Daily Mail, 18 February 1988, 4A.

Chinn, Sandra. “Don’t Let the Selling of Coal Compromise State’s Clean Air.” Charleston Daily Mail, 25 March 1988, 4A.

Christian, J.A. “Capitol Plaza Hosts Lively Radio Program.” Charleston Daily Mail, 30 January 1988, 4A. 
Collins, Lee. “Consolidate Schools; Open State to Casinos.” Charleston Daily Mail, 25 March 1988, 5A.

Cooper, Thornton. “Consolidation Plans are Off Base as Usual.” Charleston Daily Mail, 21 December 1987, 4A.

Davis, Christina K. "Re-evaluate the Proposal to Close Loudendale School.” Charleston Daily Mail, 15 March 1988, 4A.

Davis, Michael W. "Buckle Your Seat Belts and Enjoy the Holidays.” Charleston Daily Mail, 21 December 1987, 4A.

Ellison, Joan M. “Politicians Raiding Every Fund Available.” Charleston Daily Mail, 30 January 1988, 4A.

Fellure, Jim. "Politicians Should be Acquainted with God.” Charleston Daily Mail, 25 March 1988, 5A.

Ferrell, Kenneth. “Where’s the Volkswagen and Where’s the Preacher?” Charleston Daily Mail, 21 December 1987, 4A.

Holiday, Susan. “Teachers Deserve Respect of Society.” Charleston Daily Mail, 25 March 1988, 5A.

Hughes, Louise. “Let the Elderly Keep Their Vans.” Charleston Daily Mail, 24 February 1988, 5A.

Keeney, Helen. “W.Va. Jobs Belong to West Virginians.” Charleston Daily Mail, 24 February 1988, 5A.

Lucas, Glenn D. “Merry Casto was a Very Good Friend.” Charleston Daily Mail, 24 February 1988, 5A.

MacLean, Mary. “No One Can Replace Byrd in U.S. Senate.” Charleston Daily Mail, 24 February 1988, 5A.

Mali, Cyrus J. “Bahais Persecuted in Iran, Egypt, Morocco.” Charleston Daily Mail, 24 February 1988, 5A.

Marsh, Grey, Jr. “U.S. has Two Fists to Defeat Communists.” Charleston Daily Mail, 24 February 1988, 5A.

Maxwell, Rev. Jack. “Don’t Use Tax Money to Kill Unborn Babies.” Charleston Daily Mail, 15 March 1988, 4A. 
McClanahan, Jason. “America’s Best Athletes are Barred from Olympics.” Charleston Daily Mail, 25 March 1988, 4A.

Means, Jean. "Seat Belts for Kids are Great, but a Real Insult to the Adults.” Charleston Daily Mail, 24 February 1988, 4A.

Miller, Tom. “Don’t Use Courts to Stage Vendettas.” Charleston Daily Mail, 18 February 1988, 4A.

Moore, Bernice M. “Ambler Ridge is No Dump Site.” Charleston Daily Mail, 24 February 1988, 5A.

Neary, Reggie. “Soft Drink No Luxury for Consuming Public.” Charleston Daily Mail, 24 February 1988, 5A.

Nicholas, Connie. “Don’t Use Animals for Lab Experiments.” Charleston Daily Mail, 25 March 1988, 5A.

Pratt, B.E. “Taxpayers Must Reject Permanent Excess Levy.” Charleston Daily Mail, 18 February 1988, 4A.

Rollins, Charles. “The New Civil Rights Law Could Dictate to Churches.” Charleston Daily Mail, 25 March 1988, 4A.

Rose, C.E. “State Big Shots are All Overpaid.” Charleston Daily Mail, 15 March 1988, $4 \mathrm{~A}$.

Ross, Dennis. “Food Stamp Recipients Should Pay Food Tax.” Charleston Daily Mail, 30 January 1988, 4A.

Shoffner, Ray. “No Casino Gaming and No Decent Jobs.” Charleston Daily Mail, 24 February 1988, 5A.

. “Tonkovich and Senate are Embarrassing to State.” Charleston Daily Mail, 25 March 1988, 4A.

Smith, Richard N. “Boone Water Park was a Creative Idea.” Charleston Daily Mail, 25 March 1988, 5A.

Steelhammer, Pamela G. “Tax-Form Revisions Will be More Complicated in 1989.” Charleston Daily Mail, 24 February 1988, 4A.

Watts, Bobbi. “Money Problems Not State Workers’ Fault.” Charleston Daily Mail, 24 February 1988, 5A. 
Williams, Jesse W. “The Elderly Deserve All the Help They Get.” Charleston Daily Mail, 18 February 1988, 5A.

Williams, Mary Sue. “New Teachers Face Drugs, No Respect.” Charleston Daily Mail, 24 February 1988, 5A.

Zinn, Jerry K. “Editorial was Wrong about Jay Wolfe’s Bid.” Charleston Daily Mail, 18 February 1988, 4A.

\section{Huntington Herald-Dispatch}

\section{Independent}

\section{Editorials}

“Customs of Christmas.” Huntington Herald-Dispatch, 24 December 1970, 4.

“Distorted Priorities.” (Huntington) Herald-Advertiser, 25 April 1971, 10.

“Doctor Shortage Worsens.” (Huntington) Herald-Dispatch \& Advertiser, 14 November $1970,4$.

“Double Standard Gives Congress Big Advantage.” Huntington Herald-Dispatch, 14 April 1971, 4.

“Fresh Start in Georgia.” Huntington Herald-Dispatch, 15 January 1971, 4.

“It’s an Old Tune.” (Huntington) Herald-Advertiser, 25 April 1971, 10.

“New Health and Safety Law.” Huntington Herald-Dispatch, 27 April 1971, 4.

“New Prexy Must Share 'Marshall Love Affair'.” Huntington Herald-Dispatch, 15 January 1971, 4.

“On a Productivity Basis, Congressmen are Overpaid.” Huntington Herald-Dispatch, 24 December 1970, 4.

“The ‘One-Stop-Shop’.” Huntington Herald-Dispatch, 7 December 1970, 4.

“Pollution Can be Checked.” (Huntington) Herald-Dispatch \& Advertiser, 14 November 1970, 4.

“Riverfront Revivals.” (Huntington) Herald-Advertiser, 25 April 1971, 10.

“That Stadium Memorial.” Huntington Herald-Dispatch, 14 April 1971, 4. 
“Why Mr. Nixon Opposes Price and Wage Controls.” Huntington Herald-Dispatch, 7 December 1970, 4.

“Will They Want to Quit?” Huntington Herald-Dispatch, 27 April 1971, 4.

\section{Columns}

Adams, George M. “Christ Time!” Huntington Herald-Dispatch, 24 December 1970, 4.

. “Home Ties.” Huntington Herald-Dispatch, 15 January 1971, 4.

. “Life Left Behind.” Huntington Herald-Dispatch, 27 April 1971, 4.

. “Our Institutions.” Huntington Herald-Dispatch, 14 April 1971, 4.

. “Steam Pressure.” Huntington Herald-Dispatch, 7 December 1970, 4.

. "The Still Waters.” (Huntington) Herald-Dispatch \& Advertiser, 14

November 1970, 4.

Alsop, Joseph. “At Offutt Air Force Base, They Worry Over Estimates.” Huntington Herald-Dispatch, 14 April 1971, 4.

Anderson, Jack. “Senator's Wife Helping Indians.” (Huntington) Herald-Dispatch \& Advertiser, 14 November 1970, 4.

Baker, Russell. "How Fortunate We are that Kaiser Did Not Win First World War." Huntington Herald-Dispatch, 27 April 1971, 4.

. “It All Began with Some Problems.” Huntington Herald-Dispatch, 14 April 1971, 4.

. "Specialized Speech Fails to Assist Boy-Girl Affair.” Huntington HeraldDispatch, 15 January 1971, 4.

Bombeck, Erma. “Hearts and Flowers.” Huntington Herald-Dispatch, 15 January 1971, 4. $1971,4$. 4. . "Our Christmas Workshop.” Huntington Herald-Dispatch, 7 December 1970,

Buchwald, Art. “Christmas Card Credit.” Huntington Herald-Dispatch, 24 December 1970, 4. 
10 .

“The Solution to Welfare.” (Huntington) Herald-Advertiser, 25 April 1971,

. “We're Being Polled to Death.” Huntington Herald-Dispatch, 27 April 1971, 4.

Buckley, William F., Jr. “'Investigative Reporting' in the Manner of the Late Drew Pearson.” Huntington Herald-Dispatch, 24 December 1970, 4.

Chamberlain, John. “Albany University Rocky’s Pride.” Huntington Herald-Dispatch, 7 December 1970, 4.

. “Deep Sea May Start Island Boom.” Huntington Herald-Dispatch, 15 January 1971, 4. 4.

. “Young Senators Cite 'Truth'.” Huntington Herald-Dispatch, 14 April 1971,

Collins, Thomas. “The Golden Years: Make No Little Dreams...Retired Told to Think Big.” (Huntington) Herald-Dispatch \& Advertiser, 14 November 1970, 4.

Evans, Rowland and Robert Novak. "City Mayors Demand Revenue-Sharing." Huntington Herald-Dispatch, 27 April 1971, 4.

. “Cleaning Up Legal Services Mess.” Huntington Herald-Dispatch, 7 December 1970, 4.

. “The 'End Run’ Around Fulbright.” Huntington Herald-Dispatch, 15 January 1971, 4.

. "Kennedy Backers (and Maybe Teddy Himself) Haven’t Given Up Hope.”

Huntington Herald-Dispatch, 24 December 1970, 4.

. “Liberal Democrats Raised Money for McCloskey’s Journey to Laos.”

(Huntington) Herald-Advertiser, 25 April 1971, 10.

Lawrence, David. "Breakdown in Communications Reason for Anti-War

Demonstrations.” Huntington Herald-Dispatch, 27 April 1971, 4.

. "Inflation Gets Another Assist." (Huntington) Herald-Dispatch \& Advertiser, 14 November 1970, 4.

Little, Herb. "Youth Vote May be Ratified Before it Can Get Test in W.Va." (Huntington) Herald-Advertiser, 25 April 1971, 11. 
Miller, Tom D. "Redistricting Committee Should Include Cabell Delegate.” (Huntington) Herald-Advertiser, 25 April 1971, 11.

Pinckard, H.R. “A Personal Column.” (Huntington) Herald-Advertiser, 25 April 1971, 10.

Reed, Rufus M. “A Visit with Nature: Improving the Environment.” (Huntington) Herald-Advertiser, 25 April 1971, 10.

Reston, James. "Nixon Turns to Future in Planning New Budget.” Huntington HeraldDispatch, 7 December 1970, 4.

. "The Un-Merry City at Christmas Time.” Huntington Herald-Dispatch, 24 December 1970, 4.

. "When Greatness is Weakness." (Huntington) Herald-Dispatch \& Advertiser, 14 November 1970, 4.

. "William Rogers—Quiet, Effective.” (Huntington) Herald-Advertiser, 25 April 1971, 11.

Sherman, George. "Mission to Middle East Delicate.” (Huntington) Herald-Advertiser, 25 April 1971, 11.

\section{Letters}

Adams, Elizabeth. "Release the Scores.” (Huntington) Herald-Advertiser, 25 April 1971, 28.

Adams, Virginia W. “Quality Education.” (Huntington) Herald-Advertiser, 25 April 1971, 28.

Roush, Phillip W. "Parking Meters.” (Huntington) Herald-Advertiser, 25 April 1971, 10, 28.

Richardson, R.S. “The Railroad Worker.” (Huntington) Herald-Advertiser, 25 April 1971, 28.

Withers, Mrs. Carl. “’Nosebleed'.” (Huntington) Herald-Advertiser, 25 April 1971, 28.

\section{$\underline{\text { Non-independent }}$}

\section{Editorials}

“Action, Not 'Additional Study,' Needed on Replacement for Aging Gallipolis Dam.” Huntington Herald-Dispatch, 19 May 1972, 4. 
“And the Winner is....” Huntington Herald-Dispatch, 19 May 1972, 4.

“A Certain Election Issue.” (Huntington) Herald-Dispatch \& Advertiser, 10 June 1972, 4.

“Coal Companies, Not Taxpayers, Should Pay the Cost of Black Lung Compensation.” Huntington Herald-Dispatch, 23 May 1972, 4.

"Despite Publicity Given Small Gains, Building Trades Still Lag Badly in Jobs for Minorities.” Huntington Herald-Dispatch, 24 May 1972, 4.

“Examination of his Record Clearly Shows Arch Moore has Won Right to Second Term.” Huntington Herald-Dispatch, 16 October 1972, 4.

“A Few Questions - and Answers - that are at the Heart of the Tri-State Bus Dispute.” Huntington Herald-Dispatch, 1 June 1972, 4.

“A Good Start at MU.” Huntington Herald-Dispatch, 24 May 1972, 4.

“Meeting the Adkins Clan.” Huntington Herald-Dispatch, 23 May 1972, 4.

“New Private Buses?” Huntington Herald-Dispatch, 1 June 1972, 4.

“Not Just Words....” (Huntington) Herald-Advertiser, 24 September 1972, 12.

“Passage of \$200 Million Bond Issue Would Mean 'Better Schools,' but How Many? Where?” (Huntington) Herald-Advertiser, 24 September 1972, 12.

"Sen. Byrd on Target with His Criticisms of Way the Kleindienst Nomination Handled." (Huntington) Herald-Dispatch \& Advertiser, 10 June 1972, 4.

\section{Columns}

Anderson, Jack. "Visiting Nixon Told Russians They'd be Foolish to Start War with Chinese Reds.” (Huntington) Herald-Dispatch \& Advertiser, 10 June 1972, 4.

Baisden, Harry L. “Speaking of Misdemeanors.” Huntington Herald-Dispatch, 24 May 1972, 4.

Baker, Russell. “The Moscow Visit: 'Patton’ and a Chess Game.” Huntington HeraldDispatch, 19 May 1972, 4.

. “Paw-Paw P. Sycamore: He’s a Busy Man Indeed.” Huntington HeraldDispatch, 24 May 1972, 4.

Bell, Jack. “The Hawks and the Doves.” Huntington Herald-Dispatch, 1 June 1972, 4. 
Bombeck, Erma. “It Seems Doctors aren’t the Only Ones Asked for Advice.” Huntington Herald-Dispatch, 24 May 1972, 4.

. "School Bus Driver: Six Weeks on Job Must be a Record.” Huntington Herald-Dispatch, 16 October 1972, 4.

. "Show Me a Child with Manners, and I'll Show You....” Huntington HeraldDispatch, 19 May 1972, 4.

Broder, David S. “Smugness.” (Huntington) Herald-Advertiser, 24 September 1972, 12.

Buchwald, Art. "The Day the United States Ran Out of Bombs.” Huntington HeraldDispatch, 1 June 1972, 4.

. “Is He Going to Outlaw Gin?” (Huntington) Herald-Advertiser, 24

September 1972, 12.

. “No Peace Until Every One Owns a Handgun.” Huntington Herald-Dispatch, 23 May 1972, 4.

Buckley, William F., Jr. “Cuts Proposed by Sen. McGovern in Defense Spending Would be ‘a Giant Step Backwards’.” Huntington Herald-Dispatch, 23 May 1972, 4.

. "Soviets Put Up with U.S. Trade Exhibits as the 'Price' for Sending Students Here.” (Huntington) Herald-Advertiser, 24 September 1972, 12.

. "That Constitutional Phrase Concerning Church and State-is it Still Needed?” Huntington Herald-Dispatch, 1 June 1972, 4.

Casto, James E. “You Can’t Get There from Here.” (Huntington) Herald-Dispatch \& Advertiser, 10 June 1972, 4.

Evans, Rowland and Robert Novak. "At Long Last, it Appears Hanoi's Leaders are Seriously Interested in Negotiations.” Huntington Herald-Dispatch, 16 October 1972, 4.

. "Eagerness of Brezhnev to go Ahead with Nixon Meeting Makes Success Vital to Him.” Huntington Herald-Dispatch, 24 May 1972, 4.

. "Real Reasons Behind Connally Departure are Unexciting: He was Bored, His Wife Unhappy.” Huntington Herald-Dispatch, 19 May 1972, 4.

Germond, Jack W. “Wallace Vote Margins ‘Distorted’?” Huntington Herald-Dispatch, 19 May 1972, 4. 
Hoppe, Arthur. “Why Not Firearms for the Deserving Poor?” Huntington HeraldDispatch, 16 October 1972, 4.

Mayne, Don. "Campaigning: the Same Crowds, Same Shouts and Promises...." (Huntington) Herald-Advertiser, 24 September 1972, 13.

Patterson and Patrick. "Presidents of Manifest Destiny.” Huntington Herald-Dispatch, 16 October 1972, 4.

Reed, Rufus M. “Mystery of the Cattle Egrets.” (Huntington) Herald-Advertiser, 24 September 1972, 13.

Reston, James. “The Nixon-Brezhnev Agenda.” Huntington Herald-Dispatch, 23 May 1972, 4.

Smith, Jack. "Back to Nature-the Worm in One's Apple.” (Huntington) HeraldDispatch \& Advertiser, 10 June 1972, 4.

\section{Letters}

Blair, Mrs. Robert E. Untitled Letter to the Editor. (Huntington) Herald-Advertiser, 24 September 1972, 12.

Gardner, Richard W., M.D. “Chess Coverage.” (Huntington) Herald-Advertiser, 24 September 1972, 13.

Nelson, Robert R. “A Thank-You.” (Huntington) Herald-Advertiser, 24 September 1972, 12-13.

Rodgers, Brooke. “The Black Bear.” (Huntington) Herald-Advertiser, 24 September 1972, 13.

Sizemore, Charlene P. “MU Engineering.” Huntington Herald-Dispatch, 23 May 1972, 4.

Sullivan, Ruth C. “East Bridge.” Huntington Herald-Dispatch, 1 June 1972, 4.

(Keyser) Mineral Daily News-Tribune

\section{Independent}

\section{Editorials}

Beavers, Liz. "From the Editor's Desk...Is this the Newsroom ...or the Twilight Zone?” (Keyser) Mineral Daily News-Tribune, 21 January 1998, 3. 
State editorials compiled by the Associated Press and printed in the Mineral NewsTribune \& Echo.

Untitled Editorial. Beckley Register-Herald as reprinted in the (Keyser) News-Tribune \& Echo, 21 March 1998, 3.

Untitled Editorial. Huntington Herald-Dispatch as reprinted in the (Keyser) NewsTribune \& Echo, 21 March 1998, 3.

\section{Columns}

Kidner, John P. "The Word from Washington...The New Mr. and Mrs. Kidner Thank You.” (Keyser) News-Tribune \& Echo, 21 March 1998, 3.

Raum, Tom. “Clinton Has New 'Hands-Off' Tactics.” (Keyser) News-Tribune \& Echo, 21 March 1998, 3.

\section{Letters}

Carriger, Harley M. “We Don’t Need this Type of Reform.” (Keyser) Mineral Daily News-Tribune, 21 January 1998, 3.

Harris, May. "Please, Help Feed the Wild Animals.” (Keyser) Mineral Daily NewsTribune, 21 January 1998, 3.

Jeffries, Dawn S. “Beware: Changes are Coming Soon.” (Keyser) Mineral Daily NewsTribune, 21 January 1998, 3.

\section{Non-independent}

\section{Editorials}

\section{Opinions from Around the State as Featured on the Editorial Page}

Untitled Editorial. Charleston Daily Mail as reprinted in the (Keyser) Mineral Daily News-Tribune, 23 August 1999, 3.

Untitled Editorial. Clarksburg Exponent-Telegram as reprinted in the (Keyser) Mineral Daily News-Tribune, 23 August 1999, 3.

Untitled Editorial. Logan Banner as reprinted in the (Keyser) Mineral Daily NewsTribune, 23 August 1999, 3. 


\section{Columns}

Davidson, Jim. “Sorry I Haven’t Written Mother.” (Keyser) Mineral Daily News-Tribune, 23 August 1999, 3.

Johnson, Rheta Grimsley. “The Places that Inspire the Pen.” (Keyser) Mineral Daily News-Tribune, 23 June 1999, 3.

Kidner, John. "The Word from Washington...An Annoying Sound, a Hunk of Wood Across the Backside.” (Keyser) News-Tribune \& Echo, 6 November 1999, 3A.

McGreevy, Kimi-Scott. "Who Cares How the Phone Call Gets to the House...Just so it Does.” (Keyser) News-Tribune \& Echo, 6 November 1999, 3A.

O’Brien, Jeff. “The Willowbrook Whalloper.” (Keyser) Mineral Daily News-Tribune, 23 August 1999, 3.

Wagoner, Pat. "County's First Relay for Life Dedicated to Can-Do Cannon.” (Keyser) Mineral Daily News-Tribune, 23 June 1999, 3.

Wilson, Sally. “Friends, Family Mean Everything.” (Keyser) News-Tribune \& Echo, 6 November 1999, 4A.

\section{Letters}

Baker, Dave. "Ex-Administrator Responds to Resignation Theory.” (Keyser) NewsTribune \& Echo, 6 November 1999, 4A.

Dolechek, Judy. “After 58 Years, Bob Dorsey's Still Going Strong with Keyser VFD.” (Keyser) News-Tribune \& Echo, 6 November 1999, 3A.

Dyer, Rick. "Reader to Ex-City Officials: Action Speaks Louder than Words." (Keyser) News-Tribune \& Echo, 6 November 1999, 4A.

Thompson, Betty. "Reader Blasts Keyser Mayor's Plans to Replace Chief, City Administrator.” (Keyser) Mineral Daily News-Tribune, 23 June 1999, 3.

\section{Logan Banner}

\section{$\underline{\text { Independent }}$}

\section{Editorials}

“Banking’s New Look.” Logan Banner, 27 October 1964, 4.

“Be Merry, Anyhow.” Logan Banner, 24 December 1964, 4. 
“How Green is Our Crater.” Logan Banner, 9 October 1964, 4.

“An Item of Urgency.” Logan Banner, 9 October 1964, 4.

“The Kids’ Again.” Logan Banner, 23 November 1964, 4.

“Let’s Equalize ‘Equal Time’.” Logan Banner, 27 October 1964, 4.

“Living Tribute to Churchill.” Logan Banner, 23 November 1964, 4.

“A New Freedom of Actions.” Logan Banner, 17 February 1965, 4.

“The Price of Compassion.” Logan Banner, 13 February 1965, 4.

“The Real Spirit of Christmas.” Logan Banner, 24 December 1964, 4.

“She Knows Best.” Logan Banner, 13 February 1965, 4.

“Slow to Learn?” Logan Banner, 17 February 1965, 4.

\section{Columns}

Biossat, Bruce. “The Washington Report.” Logan Banner, 23 November 1964, 4.

Boyle, Hal. “Today with Hal Boyle.” Logan Banner, 17 February 1965, 4.

Brandstadt, Wayne G. “The Doctor Says.” Logan Banner, 24 December 1964, 4. . “The Doctor Says: Vaccines Fight Viral Invaders.” Logan Banner, 17 February 1965, 4.

Cannel, Ward. “Cannel at Bay: The Key to Brilliance—Just be Adequate.” Logan Banner, 17 February 1965, 4.

Cromley, Ray. “The Washington Report.” Logan Banner, 9 October 1964, 4. . “The Washington Report.” Logan Banner, 27 October 1964, 4. . “The Washington Report.” Logan Banner, 24 December 1964, 4. . “The Washington Report: LBJ: Weak Hand for Big Stakes.” Logan Banner, 13 February 1965, 4.

. “The Washington Report: Mao Leery of Another Korea.” Logan Banner, 17 February 1965, 4. 
Dawson, Sam. “Business Mirror: Profit Time Again.” Logan Banner, 9 October 1964, 4. 4. . “Business Mirror: 'Sick Getting Better'”’ Logan Banner, 27 October 1964, 4. 4.

. “Business Mirror: Tax Cut Probable.” Logan Banner, 23 November 1964, . “Today’s Business Mirror: 'Fever Chart' Varies.” Logan Banner, 17 February 1965, 4.

. “Week in Business: He’s Really Loaded.” Logan Banner, 24 December 1964, 4.

Dennen, Leon. “The Global View: 'Religious Virus’ Infecting Soviet Army.” Logan Banner, 13 February 1965, 4.

Hylton, Charlie. “By the Way.” Logan Banner, 13 February 1965, 4.

Kleiner, Dick. “The Show Beat.” Logan Banner, 9 October 1964, 4. . “The Show Beat.” Logan Banner, 27 October 1964, 4. . “The Show Beat.” Logan Banner, 23 November 1964, 4. . “The Show Beat.” Logan Banner, 24 December 1964, 4.

\section{Letters}

Adkins, Mrs. V.M. Untitled Letter to the Editor. Logan Banner, 13 February 1965, 4.

Fitzpatrick, Charles. Untitled Letter to the Editor. Logan Banner, 13 February 1965, 4.

Jewel, Mrs. Kitty. Untitled Letter to the Editor. Logan Banner, 9 October 1964, 4.

\section{Non-independent}

“Airline Mechanics Voice Opinion of Government Interference.” Logan Banner, 4 August 1966, 4.

“Bones of Contention.” Atlanta Constitution as reprinted in the Logan Banner, 8 April 1966, 4.

“Collector’s Items.” Chicago Tribune as reprinted in the Logan Banner, 18 April 1966, 4.

“The Days of Summer...So Ever Carefully.” Logan Banner, 21 May 1966, 4. 
“Easter Chicks a Menace.” Logan Banner, 8 April 1966, 4.

"Economy Class." Atlanta Constitution as reprinted in the Logan Banner, 4 August 1966, 4.

"Litter-ally Speaking." Washington Star as reprinted in the Logan Banner, September 1966, 4.

“Low Income...Writer’s Plight!” Logan Banner, 23 August 1966, 4.

“More Money Needs to be Appropriated.” Logan Banner, 21 September 1966, 4.

“'Opulent State'." Regina (Sask.) Leader-Post as reprinted in the Logan Banner, 18 April 1966, 4.

“Remember?” Windsor (Ont.) Star as reprinted in the Logan Banner, 23 August 1966, 4.

“Republicans in the South?” Logan Banner, 18 April 1966, 4.

"Short Memories." Dallas Times Herald as reprinted in the Logan Banner, 4 August 1966, 4.

“Spring Flowering.” Logan Banner, 21 May 1966, 4.

“Texas Moon.” Dallas Times Herald as reprinted in the Logan Banner, 23 August 1966, 4.

“Try Disinflation.” Lexington (Ky) Herald as reprinted in the Logan Banner, 18 April 1966, 4.

“Where Will Price Increases Stop?” Regina (Sask.) Commonwealth as reprinted in the Logan Banner, 8 April 1966, 4.

\section{Columns}

Biossat, Bruce. “The Washington Report: GOP Confident of House Gain.” Logan Banner, 18 April 1966, 4.

. "The Washington Report: Reagan Changes Spending Tune.” Logan Banner, 23 August 1966, 4.

Boyle, Hal. “Today with Hal Boyle.” Logan Banner, 4 August 1966, 4.

. “Today with Hal Boyle.” Logan Banner, 8 April 1966, 4.

. “Today with Hal Boyle.” Logan Banner, September 1966, 4. 
. “Today with the Hal Boyle.” Logan Banner, 23 August 1966, 4.

Brandstadt, Wayne G., M.D. “The Doctor Says: First Aid Important in Rabies Case.” Logan Banner, 4 August 1966, 4.

Cannel, Ward. “Cannel at Bay: Mr. Legion Stays Right on Top of Current Events.” Logan Banner, September 1966, 4.

Cromley, Ray. “The Washington Report: China Seeks Substitute for War.” Logan Banner, September 1966, 4.

. “The Washington Report: Failures Foul Up Russians.” Logan Banner, 8 April 1966, 4.

Cunniff, John T. “Today’s Business Mirror: Guideposts Held Key.” Logan Banner, 18 April 1966, 4.

. “Today’s Business Mirror: Madness on Wall St.” Logan Banner, September 1966, 4.

Dawson, Sam. “Today’s Business Mirror: Public is Confused.” Logan Banner, 23 August 1966, 4.

. “Today’s Business Mirror: Wages, Prices Eyed.” Logan Banner, 4 August 1966, 4.

Lefler, Jack. “Today’s Business Mirror: Steel Mills Pressed.” Logan Banner, 8 April 1966, 4.

Pritchard, Don. “About Town.” Logan Banner, 21 May 1966, 4.

Tiede, Tom. "Foxholes, Lizards, Shysters and Hairless Dogs: Tan An Hoi: Just a Typical South Vietnamese Town.” Logan Banner, 8 April 1966, 4.

. "New Breed of Bigots: Second in a Series: The Props of Nazism Surround George Rockwell.” Logan Banner, 23 August 1966, 4.

. "A White Phosphorus Grenade: Lance Corporal Bill Costello Put the Fire Out.” Logan Banner, 18 April 1966, 4.

Topolski, Feliks. "Portrait of China: Fourth of a Series: Communist Millionaires Still Can be Found in China.” Logan Banner, 4 August 1966, 4.

Washington Staff. “The Washington Report: Aussies Aim to Please.” Logan Banner, 21 May 1966, 4. 
. “The Washington Report: Well, Luci, Will That SS, etc.?” Logan Banner, 4 August 1966, 4.

\section{Letters}

Damron, Oval D. Untitled Letter to the Editor. Logan Banner, 23 August 1966, 4.

\section{Raleigh Register}

\section{Independent}

Note: Saturday, October 4, 1975 and Sunday, December 7, 1975 are also cited under Raleigh Register since they collaborated on these dates.

\section{Editorials}

“Communication.” Norfolk (Va.) Ledger-Star as reprinted in the Raleigh Register, 10 October 1975, 4.

“Cost of Sugar.” Atlanta Journal and Constitution as reprinted in the Raleigh Register, 21 July 1975, 4.

“Defining Death.” Raleigh Register, 10 October 1975, 4.

“The Disbelievers.” Charleston (S.C.) News and Courier as reprinted in the Raleigh Register, 29 October 1975, 6.

“East Macon Incident.” Macon (Ga.) News as reprinted in the Raleigh Register, 29 October 1975, 6.

“It’s Only Wasted Tax Money!” Raleigh Register, 16 September 1975, 6.

“Mrs. Thatcher’s Visit.” Raleigh Register, 16 September 1975, 6.

“The Mystery Man.” Montgomery (Ala.) Advertiser as reprinted in the Raleigh Register, 29 October 1975, 6.

“No Outside Influence in W.Va.!” Raleigh Register, 6 November 1975, 4.

"Noise Pollution.” Lubbock (Tex.) Avalanche-Journal as reprinted in the Raleigh Register, 10 October 1975, 4.

“Pension, Anybody?” Raleigh Register, 21 July 1975, 4.

“Speed Deaths Down, How Justify Hike?” (Beckley) Post-Herald and (Raleigh) Register, 4 October 1975, 6. 
“Is He Off the Dime?” (Beckley) Post-Herald and (Raleigh) Register, 7 December 1975, 6.

“Back to the Jungle?” (Beckley) Post-Herald and (Raleigh) Register, 7 December 1975, 6.

“Make the Right Change.” (Beckley) Post-Herald and (Raleigh) Register, 7 December 1975, 6.

\section{Columns}

Anderson, Jack. “'Tis the Season to be Wary: Some Pointers.” (Beckley) Post-Herald and (Raleigh) Register, 7 December 1975, 6.

. “Nixon Not Involved with Wounded Knee.” (Beckley) Post-Herald and (Raleigh) Register, 4 October 1975, 6.

Apple, R.W., Jr. “Ford’s 'Busted Pillow': Can He Pick Up the Feathers?” Raleigh Register, 6 November 1975, 4.

Baker, Russell. “Observer: Your Clothes Tell Me...” (Beckley) Post-Herald and (Raleigh) Register, 7 December 1975, 6.

Benson, Miles. “’Congressional Record’ is Rather a Farce!” Raleigh Register, 16 September 1975, 6.

Curry, Leonard. “Inflation Cause: Unemployment Insurance-Both Good, Bad?” Raleigh Register, 29 October 1975, 6.

Donnelly, Shirley. "Yesterday and Today: Manson Left a String of Crimes Behind.” (Beckley) Post-Herald and (Raleigh) Register, 4 October 1975, 6.

Growald, Richard H. “Elkins Tested SS Security, Ford’s Mettle.” Raleigh Register, 10 October 1975, 4.

Hodel, Emile J. “Top O’ the Morning: Sarandon Praised for Film Role.” (Beckley) PostHerald and (Raleigh) Register, 4 October 1975, 6.

Hodel, John. “Bug Dust: A Rainy Sunday’s Noises are (Too?) Muted.” Raleigh Register, 21 July 1975, 4.

. "Bug Dust: Meaning, Understanding Are Most Important!” (Beckley) PostHerald and (Raleigh) Register, 7 December 1975, 6.

. “Bug Dust: Plumbing Noises are Universal?” Raleigh Register, 6 November 1975, 4. 
. "Bug Dust: 'Senseless’ Bombing is Redundant Headline?” Raleigh Register, 29 October 1975, 6.

. “Bug Dust: Try Using Topless Dancers Against Terrorists?” Raleigh Register, 16 September 1975, 6.

Hoppe, Arthur. “The Innocent Bystander: Good-Bye, Liberty.” Raleigh Register, 10 October 1975, 4.

Kohler, Saul. “The Presidency: Campaigning is Tough All but Jimmy.” (Beckley) PostHerald and (Raleigh) Register, 7 December 1975, 6.

Landau, Jack C. “The Law Column: Press, Public Have Stake in Mandel Case.” (Beckley) Post-Herald and (Raleigh) Register, 7 December 1975, 7.

Lewis, Anthony. "Black Political Figure Reminisces: The 'Wait' Period is Dangerous.” Raleigh Register, 16 September 1975, 6.

. “The American Dream: Can We Remain 'Humanized’?” Raleigh Register, 29 October 1975, 6.

Lisagor, Peter. “Not America’s Bag: Ford’s China Trip Meaningless.” (Beckley) PostHerald and (Raleigh) Register, 7 December 1975, 7.

. “Whipping Up a Wondrous Storm.” Raleigh Register, 21 July 1975, 4.

Morrow, Stephen. "Foreign News Commentary: New Peru Ruler Refreshingly Different.” Raleigh Register, 6 November 1975, 4.

Pope, LeRoy. A \& P Restructuring 95\% Complete.” Raleigh Register, 21 July 1975, 4. . "Uncle Sam will Help with OSHA Changes.” Raleigh Register, 6 November 1975, 4.

Reston, James. “Can Ford Win Without Even Dressing for the Game?” Raleigh Register, 16 September 1975, 6.

. “Cheer Up! Things are Terrible.” (Beckley) Post-Herald and (Raleigh) Register, 7 December 1975, 7.

Sawislak, Arnold. “Ho-Hum, is the Word for Politics Just Now.” Raleigh Register, 29 October 1975, 6.

Schwartz, Harry. “Mathews Going to HEW; Must Be Exceptionally Brave.” Raleigh Register, 21 July 1975, 4. 
Sulzberger, C.L. "Foreign Affairs: Brazil: An Elephant in the Bed.” (Beckley) PostHerald and (Raleigh) Register, 7 December 1975, 7.

Thomas, Helen. “Betty Ford is Very Much Her Own Woman.” Raleigh Register, 10 October 1975, 4.

. “Kissinger Takes a Look at Mid-America.” Raleigh Register, 21 July 1975, 4.

Tully, Andrew. "Heroic Acts are Forgotten; Freaks Get the Applause.” (Beckley) PostHerald and (Raleigh) Register, 4 October 1975, 6.

Wicker, Tom. “Demo Politics: New Faces are Looking Better.” Raleigh Register, 29 October 1975, 6.

. "In the Nation: Power and Corruption.” (Beckley) Post-Herald and (Raleigh) Register, 7 December 1975, 7. 1975, 4.

. "The Reagan Threat: Mr. Ford and the Right.” Raleigh Register, 6 November . “Why the Italians Vote Communist.” Raleigh Register, 10 October 1975, 4.

Wills, Bob. “Bug Dust: It’s Difficult to Keep the Record Straight.” Raleigh Register, 10 October 1975, 4.

\section{Letters}

Smith, Larry O. “Seeks Mail.” (Beckley) Post-Herald and (Raleigh) Register, 7 December 1975, 7.

Watkins, James H. “New River Fund Goal Met; Battle Still On.” (Beckley) Post-Herald and (Raleigh) Register, 7 December 1975, 7.

\section{Non-independent}

Note: Monday, May 30, 1977, Saturday, April 9, 1977 and Sunday, May 1, 1977 are also cited under Beckley Post-Herald since they collaborated on these dates.

\section{Editorials}

“Carter’s Election Reform Scary.” Raleigh Register, 23, March 1977, 4.

“Chance to Save.” Raleigh Register, 11 January 1977, 4.

“The Difference.” Raleigh Register, 11 January 1977, 4. 
“Don’t Believe It.” Raleigh Register, 10 February 1977, 4.

“Don’t Cheer Yet.” (Beckley) Post-Herald and (Raleigh) Register, 9 April 1977, 4.

“Food Prices.” Raleigh Register, 22 April 1977, 4.

“Free Again!” New York Times as reprinted in the Raleigh Register, 23 March 1977, 4.

“Pet Owners Conned.” (Beckley) Post-Herald and (Raleigh) Register, 9 April 1977, 4.

“Public Papers.” Editor \& Publisher as reprinted in the Raleigh Register, 22 April 1977, 4.

“Say it with...?” Raleigh Register, 10 February 1977, 4.

“Singlaub’s Views Interest Solons.” (Beckley) Post-Herald and (Raleigh) Register, 30 May 1977, 4.

“So What!” (Beckley) Post-Herald and (Raleigh) Register, 9 April 1977, 4.

“Uneasy Over Belgrade.” (Beckley) Post-Herald and (Raleigh) Register, 30 May 1977, 4.

"Young Too Erratic for U.N. Position.” (Beckley) Post-Herald and (Raleigh) Register, 9 April 1977, 4.

\section{Columns}

Amick, Dorothy. "Bug Dust: Martin Luther Bragg: An Old Friend.” (Beckley) PostHerald and (Raleigh) Register, 9 April 1977, 4.

Anderson, David E. "Religion in America: Slowing 'Mergers'.” (Beckley) Post-Herald and (Raleigh) Register, 9 April 1977, 4.

Anderson, Jack. "Fears of Inflation Grow.” (Beckley) Post-Herald and (Raleigh) Register, 9 April 1977, 4.

. "Human Rights Fight Means: U.S. Must Cut Ties with Dictators." (Beckley) Post-Herald and (Raleigh) Register, 9 April 1977, 4.

. "Rifle Association Caught in Backfire." (Beckley) Post-Herald and (Raleigh) Register, 30 May 1977, 4.

Anderson, John. "Bug Dust: Who Needs Salt? Let it Snow!” Raleigh Register, 11 January 1977, 4. 
Baker, Russell. “Observer: Lunch of Champions.” (Beckley) Post-Herald and (Raleigh) Register, 9 April 1977, 4. 4. . “Observer: Pans, Pains and Tire Chains.” Raleigh Register, 11 January 1977,

Donnelly, Shirley. “Yesterday and Today: Jones Story Living Legend---I.” (Beckley) Post-Herald and (Raleigh) Register, 30 May 1977, 4.

. "Yesterday and Today: Other Kinds of Graveyard.” (Beckley) Post- $\quad$ Herald and (Raleigh) Register, 9 April 1977, 4.

Gilmore, Daniel F. "Washington Window: Assassination Panel in Trouble.” Raleigh Register, 23 March 1977, 4.

Grigg, Joseph W. “Britain and Inflation.” Raleigh Register, 10 February 1977, 4.

Hall, Mike. "Views from the Staff: Predisposed to Violence and Death.” Beckley PostHerald, 30 May 1977, 4.

Harrigan, Anthony. "President Bows to Pressure.” (Beckley) Post-Herald and (Raleigh) Register, 30 May 1977, 4.

Hodel, Emile J. “Top O’ the Morning: Dinner Brings \$300, 000 for WVU.” (Beckley) Post-Herald and (Raleigh) Register, 9 April 1977, 4.

Hoppe, Arthur. “The Innocent Bystander: The Eve of Battle.” Raleigh Register, 11 January 1977, 4.

. “The Innocent Bystander: The House Guest.” Raleigh Register, 23 March 1977, 4.

. “The Innocent Bystander: Wife Talk." (Beckley) Post-Herald and (Raleigh) Register, 9 April 1977, 4.

Kohler, Saul. “The Presidency: Carter’s Style.” Raleigh Register, 10 February 1977, 4. . "The Presidency: The First 100 Days.” (Beckley) Post-Herald and (Raleigh) Register, 9 April 1977, 4.

Landau, Jack C. “The Law Column: Spanking.” (Beckley) Post-Herald and (Raleigh) Register, 9 April 1977, 4.

Lewis, Anthony. “Abroad at Home: Signs of Change.” (Beckley) Post-Herald and (Raleigh) Register, 9 April 1977, 4. 
Peck, Harry. "Pecknically Speaking: Myles of Pleasure.” (Beckley) Post-Herald and (Raleigh) Register, 9 April 1977, 4.

Pippert, Wesley G. “Washington Window: Carter’s Radical Idea of Power.” Raleigh Register, 22 April 1977, 4.

Reston, James. “’Open Conspiracy’.” Raleigh Register, 23 March 1977, 4.

. “President Carter and the Press.” Raleigh Register, 10 February 1977, 4.

. “The Moral Equivalent of War.” Raleigh Register, 22 April 1977, 4.

. "Where are we Going?” (Beckley) Post-Herald and (Raleigh) Register, 9 April 1977, 4.

Royko, Mike. “Something for All.” Raleigh Register, 22 April 1977, 4.

Safire, William. “Essay: Equal Justice under Leak.” (Beckley) Post-Herald and (Raleigh) Register, 9 April 1977, 4.

Sawislak, Arnold. “Carter’s Quandary: Bureaucrats and Barricades.” Raleigh Register, 11 January 1977, 4.

Thomas, Helen. “Carter’s Problem with World Morality.” Raleigh Register, 10 February 1977, 4.

Tully, Andrew. “General’s Firing in Order.” (Beckley) Post-Herald and (Raleigh) Register, 30 May 1977, 4.

. “U.S. Stand Perplexes Russians.” (Beckley) Post-Herald and (Raleigh) Register, 9 April 1977, 4.

Watson, Jerome. “Measuring Humphrey.” Raleigh Register, 11 January 1977, 4.

Wills, Bob. “Bug Dust: 1895-1901 Scott Ledger Fascinating Reading.” Raleigh Register, 10 February 1977, 4.

. “Bug Dust: A 1927 Ice Storm: Higgins Promoted.” Raleigh Register, 23 March 1977, 4. 4.

. “Bug Dust: Switch to Coal Won’t be Easy.” Raleigh Register, 22 April 1977, 


\section{Letters}

Farley, R.L. “Necessary Action.” (Beckley) Post-Herald and (Raleigh) Register, 9 April 1977, 4. 


\section{WORKS CITED}

Abbott, Eric A. and Lynn T. Brassfield. "Comparing Decisions on Releases by TV and Newspaper Gatekeepers.” Journalism Quarterly 66 (winter 1989): 853-56.

Abrams v. United States, 250 U.S. 616, 629, 40 S. Ct. 17, 22 (1919).

Akhavan-Majid, Roya, Anita Rife, and Sheila Gopinath. "Chain Ownership and Editorial Independence: A Case Study of Gannett Newspapers.” Journalism Quarterly 68 (spring/summer 1991): 59-66.

Akhavan-Majid, Roya and Timothy Boudreau. "Chain Ownership, Organizational Size, and Editorial Role Perceptions.” Journalism \& Mass Communication Quarterly 72 (winter 1995): 863-73.

Ardoin, Birthney. "A Comparison of Newspapers Under Joint Printing Contracts.” Journalism Quarterly 50 (summer 1973): 340-47.

Bantz, Charles R., Suzanne McCorkle, and Roberta C. Baade. "The News Factory.” Communication Research 7 (January 1980): 45-68.

Berkowitz, Dan. "Refining the Gatekeeping Metaphor for Local Television News." Journal of Broadcasting \& Electronic Media 34 no. 1 (1990): 55-69.

. "Television News Sources and News Channels: A Study in AgendaBuilding.” Journalism Quarterly 64 (1987): 508-13.

Blankenberg, William B. and Gary W. Ozanich. "The Effects of Public Ownership on the Financial Performance of Newspaper Corporations.” Journalism Quarterly 70 (spring 1993): 68-75.

Busterna, John C. "How Managerial Ownership Affects Profit Maximization in Newspaper Firms.” Journalism Quarterly 66 (summer 1989): 302-07, 358. . "Trends in Daily Newspaper Ownership.” Journalism Quarterly 65 (winter 1988): 831-38.

Busterna, John C. and Robert G. Picard. Joint Operating Agreements: The Newspaper Preservation Act and its Application. Norwood, NJ: Ablex Publishing Corporation, 1993.

Citizen Publishing Co. v. United States, 394 U.S. 131 (1969). 
Clapper, Raymond. Watching the World. With an introduction by Ernie Pyle. Ed. Olive Ewing Clapper. New York: Whittlesey House, 1944: 35-6.

Cohen, Bernard. The Press and Foreign Policy. Princeton: Princeton University Press, 1963: 120.

Coulson, David C. “Impact of Ownership on Newspaper Quality.” Journalism Quarterly 71 (summer 1994): 403-10.

Coulson, David C. and Anne Hansen. "The Louisville Courier-Journal's News Content after Purchase by Gannett.” Journalism \& Mass Communication Quarterly 72 (spring 1995): 205-15.

Cranberg, Gilbert, Randall Bezanson, and John Soloski. Taking Stock: Journalism and the Publicly Traded Newspaper Company. Ames, Iowa: Iowa State University Press, 2001.

Demers, David Pearce. The Menace of the Corporate Newspaper: Fact or Fiction? Ames, Iowa: Iowa State University Press, 1996.

. "Corporate Newspaper Structure, Editorial Page Vigor, and Social Change.” Journalism \& Mass Communication Quarterly 73 (winter 1996) 857-77.

Epstein, Edward Jay. News from Nowhere: Television and the News. Vintage Books ed. NY: Random House, 1974.

Fidel, Steve. "Singleton, MediaNews Group are no Strangers to the JOA Environment." http://deseretnews.com/dn/view/0,1249,230013835,00.html. Accessed on March 30, 2004.

Glasser, Theodore L., David S. Allen, and S. Elizabeth Blanks. "The Influence of Chain Ownership On News Play: A Case Study.” Journalism Quarterly 66 (autumn 1989): 607-14.

Grotta, Gerald L. "Consolidation of Newspapers: What Happens to the Consumer?” Journalism Quarterly 48 (summer 1971):245-50.

Hicks, Ronald G. and James S. Featherston. "Duplication of Newspaper Content in Contrasting Ownership Situations.” Journalism Quarterly 55 (autumn 1978): 54953.

Hynds, Ernest C. "Editorials, Opinion Pages Still Have Vital Roles at Most Newspapers.” Journalism Quarterly 61 (autumn 1984): 634-39.

. "Editors at Most U.S. Dailies See Vital Roles for Editorial Page.” Journalism Quarterly 71 (autumn 1994): 573-82. 
Lacy, Stephen, Mary Alice Shaver, and Charles St. Cyr. “The Effects of Public Ownership and Newspaper Competition on the Financial Performance of Newspaper Corporations: A Replication and Extension.” Journalism \& Mass Communication Quarterly 73, (summer 1996): 332-41.

Lewin, Kurt. Field Theory in Social Science: Selected Theoretical Papers. Ed. Dorwin Cartwright. NY: Harper \& Brothers, 1951: 176.

. "Frontiers in Group Dynamics: Channels of Group Life; Social Planning and Action Research.” Human Relations 1 (November 1947): 143-53.

. "Frontiers in Group Dynamics: Concept, Method and Reality in Science; Social Equilibria and Social Change.” Human Relations 1 (June 1947): 5-40.

MacDougall, Curtis D. Principles of Editorial Writing. Dubuque, Iowa: WM. C. Brown Co., 1973.

Matthews, Martha N. "How Public Ownership Affects Publisher Autonomy.” Journalism \& Mass Communication Quarterly 73, (summer 1996).

McCombs, Maxwell E. and Donald L. Shaw. "The Agenda-Setting Function of Mass Media.” Public Opinion Quarterly 36 (1972): 176-87.

McQuail, Denis. Mass Communication Theory. Third ed. London: Sage, 1994.

Milton, John. Areopagitica. With a commentary by Sir Richard C. Jebb. Cambridge: Cambridge University Press, 1918. Reprint, New York: AMS PRESS, 1971.

Nichols, John. “John Nichols: Cronkite Fears the Media Mergers Threaten Democracy.” www.madison.com/captimes/opinion/column/nichols/60744.php. Accessed on April 9, 2004.

Olien, C.N., P.J. Tichenor, and G.A. Donohue. "Relation Between Corporate Ownership And Editor Attitudes About Business.” Journalism Quarterly 65 (summer 1988): 259-66.

Riffe, Daniel, Charles F. Aust, and Stephen R. Lacy. "The Effectiveness of Random, Consecutive Day and Constructed Week Sampling in Newspaper Content Analysis.” Journalism Quarterly 70 (spring 1993): 133-39.

Shoemaker, Pamela J., Martin Eichholz, Eunyi Kim, and Brenda Wrigley. "Individual and Routine Forces in Gatekeeping.” Journalism \& Mass Communication Quarterly 78 (summer 2001): 233-42.

Shoemaker, Pamela J., Stephen D. Reese. Mediating the Message: Theories of Influences on Mass Media Content. NY: Longman, 1996. 
Simurda, Stephen J. “Trying to Make Editorials Sing.” Columbia Journalism Review 36 (September/October 1997): 46-49, 52.

Soloski, John. "News reporting and professionalism: Some constraints on the reporting of the news.” Media, Culture, and Society 11 (April 1989): 207-28.

Thrift, Ralph R., Jr. "How Chain Ownership Affects Editorial Vigor of Newspapers.” Journalism Quarterly 54 (summer 1977): 327-31.

. “How Chain Ownership Affects Editorial Vigor of Newspapers.” Master’s thesis, University of Oregon, 1977.

Toolan, Brian. "What Ever Happened to Local Columnists?” www.asne.org/search/index.cfm. Accessed on April 22, 2004.

Tuchman, Gaye. Making News: A Study in the Construction of Reality. NY: Free Press, 1978.

Turk, Judy VanSlyke. “Information Subsidies and Influence.” Public Relations Review 11, no. 3 (1985): 10-25.

“12 Cities Still Have JOAs: Court-approved Joint Operating Agreements Down from Over 25.” http://seattlepi.nwsource.com/business/119679_joaelsewhere29.html. Accessed on March 30, 2004.

U.S. Congress. Senate. Newspaper Preservation Act of $1970.91^{\text {st }}$ Cong., $2^{\text {nd }}$ sess., S.R., 1520 Congressional Record. 116, no. 2, daily ed. (30 January 1970): 1995-2006, 2008-18.

United States v. Citizen Publishing Co., 280 F. Supp. 978 (D. Ariz. 1968).

www.fcc.gov/ownership/. Accessed on April 8, 2004.

www.sfbg.com/News/joa/timeline.html. Accessed on November 7, 2002.

Wackman, Daniel, Donald Gillmor, Cecilie Gaziano, and Everette Dennis. "Chain Newspaper Autonomy as Reflected in Presidential Campaign Endorsements.” Journalism Quarterly 52 (autumn 1975): 411-19.

Wagenberg, Ronald H. and Walter C. Soderlund. "The Influence of Chain-Ownership on Editorial Comment in Canada.” Journalism Quarterly 52 (spring 1975): 93-98.

Weinfeld, William. "The Growth of Daily Newspaper Chains in the United States: 1923, 1926-1935.” Journalism Quarterly 13, no. 4 (1936): 357-380. 
White, David M. “The 'Gate Keeper': A Case Study in the Selection of News.” Journalism Quarterly 27 (fall 1950): 383-90. 